\title{
Urokinase Plasminogen Activator Is Localized in Stromal Cells in Ductal Breast Cancer
}

\author{
Boye Schnack Nielsen, Maxwell Sehested, Susanne Duun, Fritz Rank, \\ Susanne Timshel, Jørgen Rygaard, Morten Johnsen, and Keld Danø
}

Finsen Laboratory (BSN, MJ, KD), Department of Pathology (MS, FR), and Department of Medical Genetics (ST), Rigshospitalet, Copenhagen; Department of Pathology (SD), Bispebjerg Hospital, Copenhagen; Bartholin Institute (JR), Copenhagen; and Institute of Molecular Biology (MJ), University of Copenhagen, Copenhagen, Denmark

\begin{abstract}
SUMMARY: Urokinase plasminogen activator (UPA) regulates a proteolytic cascade that facilitates cancer invasion through degradation of the extracellular matrix, and high levels of UPA in human breast cancer tissue correlate with poor prognosis. We previously found that, in ductal breast cancer, uPA mRNA is highly expressed by myofibroblasts surrounding invasively growing cancer cells. However, the localization of uPA protein has not been settled in the published literature. Because uPA is a secreted molecule, it could conceivably be localized differently from its mRNA. We have studied the localization of uPA immunoreactivity in detail. Twenty-five cases of invasive ductal carcinoma were analyzed with three different uPA antibody preparations, all of which gave an essentially identical stromal staining pattern. Using double immunofluorescence, we identified uPA immunoreactivity in myofibroblasts and macrophages in all cases examined. Additionally, in approximately half of the tumors, we saw uPA staining of endothelial cells. In 3 of the 25 cases, a small subpopulation of the cancer cells was uPA-positive. We conclude that UPA immunoreactivity is almost exclusively associated with stromal cells, which thus play a major role in generation of proteolytic activity in ductal breast cancer. (Lab Invest 2001, 81:1485-1501).
\end{abstract}

$U$ rokinase plasminogen activator (UPA) is a serine protease that contributes to the degradation of the extracellular matrix during tissue remodeling processes such as invasion of cancer cells and trophoblasts, wound healing, and postlactational mammary gland involution (Bugge et al, 1998; Danø et al, 1985; Lund et al, 1996, 1999, 2000; Mignatti and Rifkin, 1993; Rømer et al, 1996; Sappino et al, 1989). uPA is secreted from cells as a virtually inactive proenzyme (pro-uPA), which after proteolytic activation can convert plasminogen into active plasmin (Petersen et al, 1988). Both pro-uPA and uPA bind with high affinity to a specific glycolipid-anchored cell surface receptor (UPAR) (Danø et al, 1994; Roldan et al, 1990), and upon receptor-binding of pro-uPA, plasmin generation is highly potentiated (Danø et al, 1994; Ellis et al, 1992). uPA activity is strongly inhibited by two specific plasminogen activator inhibitors, plasminogen activator inhibitor type 1 (PAl-1) and PAl-2 (Andreasen et al, 1997; Kruithof, 1988). UPA, UPAR, and PAI-1 are frequently overexpressed in cancer tissue, and high levels of any of these components are associated with poor prognosis in several types of human cancer, including breast cancer (Duffy et al, 1990; Grøndahl-

Received May 9, 2001.

This work was supported by the Danish Cancer Society, the Danish Research Academy, the Astrid Thaysen Fond, and the Copenhagen City Health Administration.

Address reprint requests to: Dr. Boye Schnack Nielsen, Finsen Laboratory, Strandboulevarden 49, 8621, DK-2100 Copenhagen O, Denmark. E-mail: schnack@finsenlab.dk
Hansen et al, 1993, 1995; Pedersen et al, 1994a, 1994b; Stephens et al, 1999).

Histochemical studies of different types of human cancer, including breast and colon cancer, have shown that stromal cells often contribute strongly to the overall levels of UPA, UPAR, and PAI-1 in the tumor tissue (Bianchi et al, 1994, 1995; Hewitt and Danø, 1996; Nielsen et al, 1996; Pyke et al, 1991a, 1991b, 1993). In ductal breast cancer, uPAR immunoreactivity is associated mainly with macrophages (Bianchi et al, 1994; Pyke et al, 1993), and PAl-1 immunoreactivity with fibroblast-like cells and also, to a lesser extent, with macrophages and endothelial cells (Bianchi et al, 1995; Pappot et al, 1995). We have previously found that virtually all UPA mRNA in breast cancer tissue is located in stromal cells identified as myofibroblasts and, only in rare cases, in some cancer cells (Nielsen et al, 1996). Matrix metalloproteases (MMPs) are also often expressed by stromal cells in cancer tissue (Heppner et al, 1996; Hewitt and Danø, 1996; Nielsen et al, 1997). These observations indicate that stromal cells play a major role in the generation and regulation of matrix degrading proteolytic activity and, thereby, in cancer invasion and metastasis (Danø et al, 1993).

This active stromal cell participation in cancer invasion has profound implications for both cancer therapy and basic cancer biology, a particularly interesting feature being strong similarities between certain types of cancer and the normal tissue remodeling processes, which can occur in the corresponding tissue, eg, between ductal breast cancer and postlactational breast involution (Johnsen et al, 1998). It is therefore 

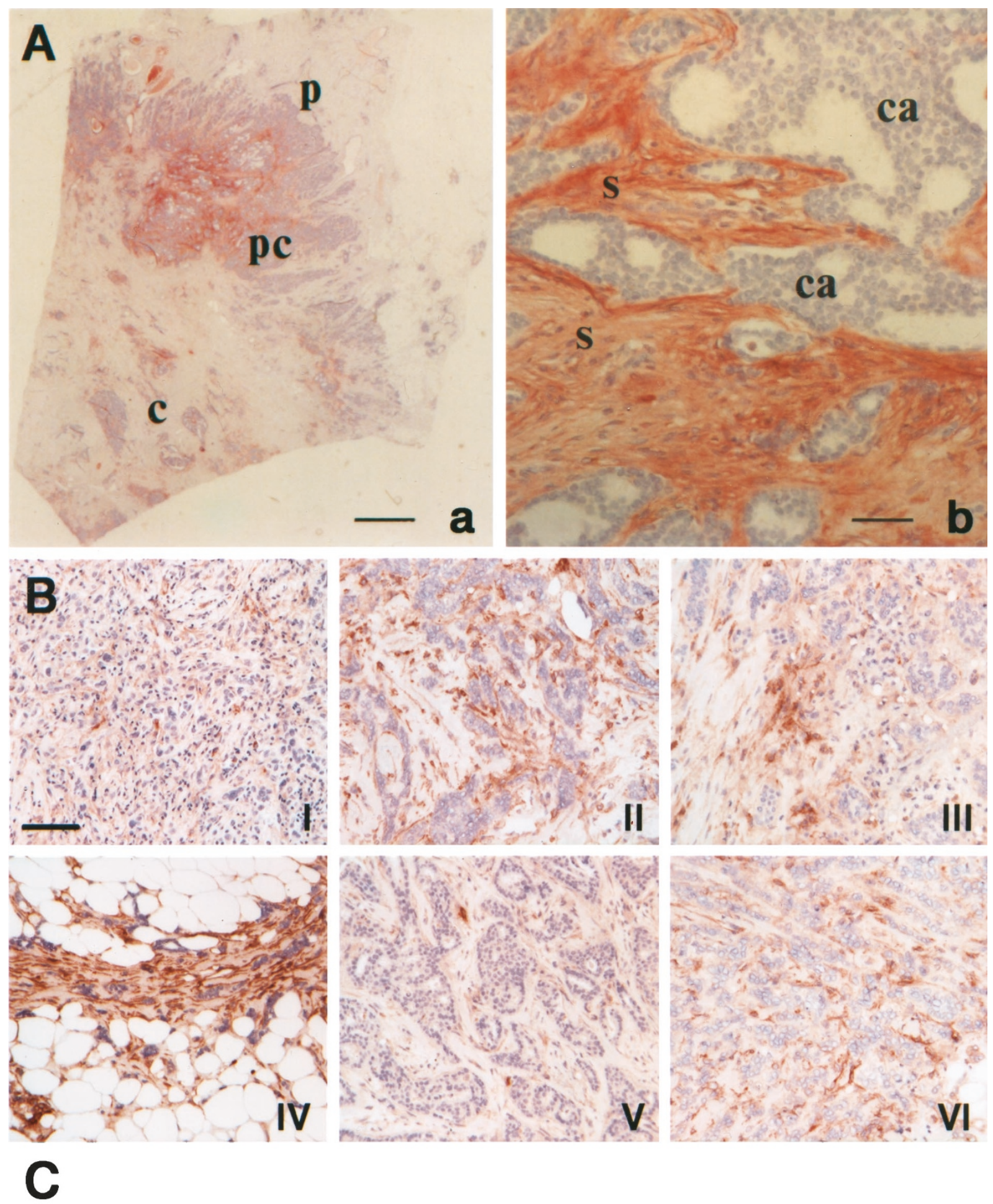

\begin{tabular}{lcccccc} 
Case & I & II & III & IV & V & VI \\
\hline $\begin{array}{l}\text { Immunohistochemistry, } \\
\text { average score }\end{array}$ & 1 & 2.3 & 2.7 & 3 & 0.3 & 2.3 \\
\hline $\begin{array}{l}\text { ELISA, } \\
\text { ng uPA/mg protein }\end{array}$ & 2.1 & 10.2 & 5.7 & 14.5 & 1.1 & 2.9 \\
\hline
\end{tabular}


important to determine in which cells UPA protein is located in breast cancer tissue. Until now, however, this issue has not been clarified, despite several immunohistochemical studies (Carriero et al, 1994; Christensen et al, 1996; Costantini et al, 1991, 1996; Damjanovich et al, 1994; Del Vecchio et al, 1993; Dublin et al, 2000; Jänicke et al, 1991; Jankun et al, 1993; Kennedy et al, 1998; Sumiyoshi et al, 1991; Visscher et al, 1993, 1995). Many groups report that the UPA immunostaining is localized exclusively or mainly in the cancer cells in contrast to the above discussed localization of uPA mRNA (Costantini et al, 1991, 1996; Damjanovich et al, 1994; Del Vecchio et al, 1993; Jänicke et al, 1991; Jankun et al, 1993; Sumiyoshi et al, 1991). In other studies, uPA immunostaining was mainly found in stromal cells (Kennedy et al, 1998; Visscher et al, 1993, 1995), whereas some authors found substantial staining of both cancer cells and stromal cells (Carriero et al, 1994; Christensen et al, 1996; Dublin et al, 2000). We have therefore undertaken the present study to contribute to a clarification of the localization of uPA protein in ductal breast cancer.

\section{Results}

\section{Localization and Specificity of uPA Immunostaining}

Specimens from 25 cases of invasive ductal breast carcinoma were immunostained for UPA using a standard $\mathrm{ABC}$ technique as described in "Materials and Methods." Briefly, the specimens were frozen, formalin fixed for 1 hour at $4^{\circ} \mathrm{C}$, paraffin embedded, and following sectioning and trypsin treatment, they were analyzed by immunohistochemistry with a mouse $\mathrm{mAb}(\beta 10)$ and a preparation of polyclonal rabbit immunoglobulin G (lgG) antibodies (pAb2) against human uPA. Immunostaining was seen in all cases, and in all cases the two antibody preparations gave a virtually identical staining, located in the stromal regions of the tumor. The intensity of the staining varied within the same specimen and from case to case. Usually, the strongest staining was found in a desmoplastic cellular stroma in the paracentral area of the tumors (Fig. 1A, Panel a). Staining was less intense in the peripheral part of the tumor area, except for a few cases in which there was an equally intense staining throughout the stroma of the whole tumor. uPA staining was most prominent in fibroblast-like cells immediately surrounding cancer cell formations in the paracentral area, where there was also a diffuse extracellular staining of the entire stroma (Fig. 1A,
Panel b). Similar staining of fibroblast-like cells was observed in the central sclerotic area; however, no staining was seen of the extracellular matrix of the sclerotic stroma (not shown). In all cases, some uPAimmunoreactive, macrophage-like cells were also observed (see below). Most of these cells were located in the tumor stroma, but a few were found intraluminally. In 12 of the 25 cases, some uPA-immunostained cells located throughout the tumor area were by morphological criteria assessed to be capillary endothelial cells. We cannot exclude that uPA-positive capillary endothelial cells were also present in some of the other 13 cases. A small subpopulation of the cancer cells was uPA-positive in 3 of the 25 cases of ductal carcinoma. Noncancerous tissue was without any detectable uPA immunostaining.

We also studied a small sample (six cases) of invasive lobular breast carcinoma. In four of these, we found UPA immunostaining that was confined to the stromal parts of the tumors and distributed identically to that described above for the ductal carcinomas. The remaining two lobular tumors were altogether negative for UPA immunostaining. Whether this relatively high proportion of UPA-negative tumors is a characteristic of lobular breast carcinoma remains to be established.

Specimens from all the 31 cases described above were also test-stained with nonimmune rabbit lgG as a negative control. No staining was seen with this IgG preparation in any of the sections. The specificity of the immunostaining obtained above was further tested by staining of five of the invasive ductal carcinomas with another preparation of rabbit polyclonal antibodies to human uPA (pAb1) and with two additional negative control antibody preparations: pAb1 preabsorbed with a purified uPA preparation $\left(\mathrm{pAb} 1^{-}\right)$and a mouse monoclonal antibody raised against tri-nitrophenyl (TNP) and having the same lgG subtype $\left(\operatorname{lgG}_{1}\right)$ as the $\beta 10$ uPA antibody. In all five cases, the pAb1 preparation gave a staining pattern identical to that found with the $\beta 10$ and pAb2 antibodies, whereas no staining was seen with either of the negative control antibody preparations (Fig. 2A). We conclude from these observations that the identical staining obtained with the three different uPA antibody preparations is specific for UPA and thus reveals the localization of genuine uPA protein in breast cancer tissue.

To further evaluate this conclusion, we compared the staining intensity obtained in tissue sections from six invasive ductal carcinomas with the UPA antigen content measured by ELISA in extracts from adjacent

\section{Figure 1.}

Urokinase plasminogen activator (UPA) immunostaining of paraffin-embedded specimens of human ductal breast cancer tissue and comparison of the staining intensities with UPA levels measured by ELISA. Tissue specimens were formalin fixed for one hour at $4^{\circ} \mathrm{C}$ and paraffin embedded. Sections (5 $\left.\mu \mathrm{m}\right)$ were trypsinized, incubated with UPA antibodies that were detected with the avidin biotin complex (ABC) peroxidase technique, developed with 3-amino-9-ethylcarbazole (AEC, red-brown color), and counterstained with Mayers hematoxylin (see "Material and Methods"). A, In the typical example, the strongest immunostaining is seen in paracentral areas ( $p c$ in Panel a and magnified in Panel b). Note that the staining is focal and that the periphery $(p)$ and central areas $(c)$ of the tumor show less intense staining (a). UPA immunostaining is seen in stromal cells ( $s$ in Panel b) whereas no staining is seen in the cancer cells (ca in Panel b). uPA was detected with the $\mathrm{mAb} \beta 10(10 \mu \mathrm{g} / \mathrm{ml})$. B, Frozen samples from six invasive ductal carcinomas were each divided into two halves. One half was pulverized and processed for uPA ELISA measurements, and the other was formalin fixed and paraffin embedded and used for uPA immunohistochemistry with pAb2 (5 $\mu \mathrm{g} / \mathrm{ml})$. The uPA stained sections were scored by three independent observers as specified in "Material and Methods." $C$, The average scores and the corresponding uPA ELISA values are shown. The Spearman rank correlation was $0.90(p<0.02)$. Bars in $\mathrm{A}: \mathrm{a}=1100 \mu \mathrm{m}, \mathrm{b}=30 \mu \mathrm{m}$; B: $100 \mu \mathrm{m}$. 


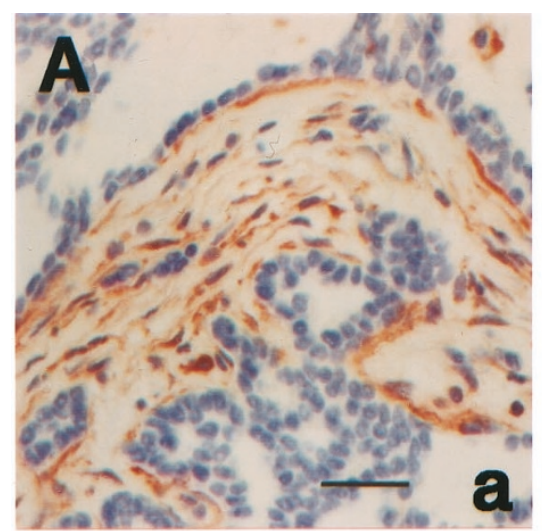

20
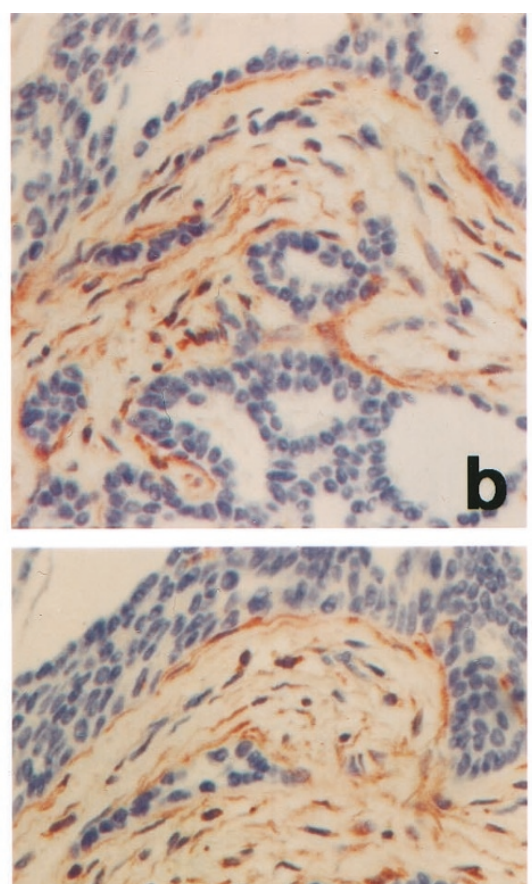

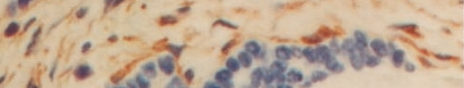

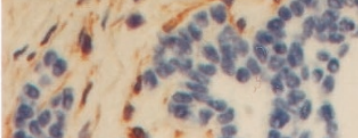

asis

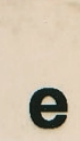

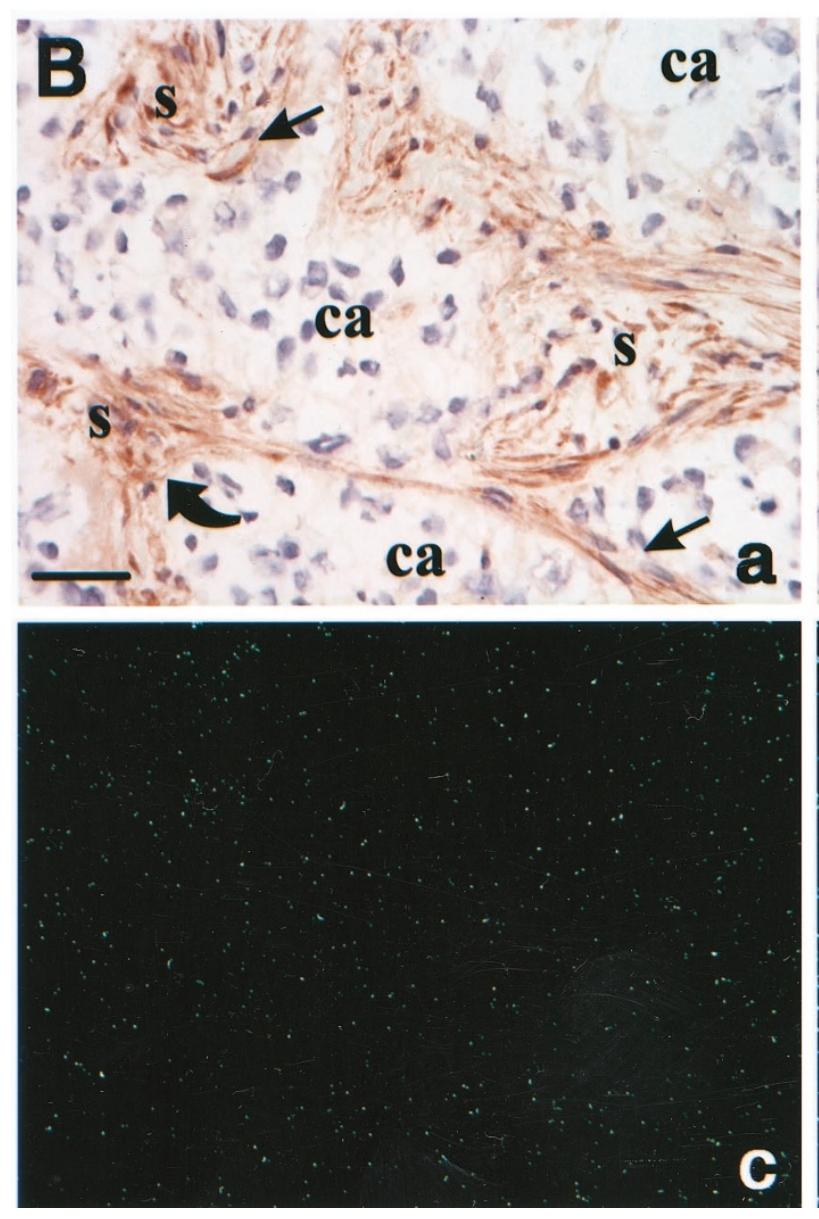

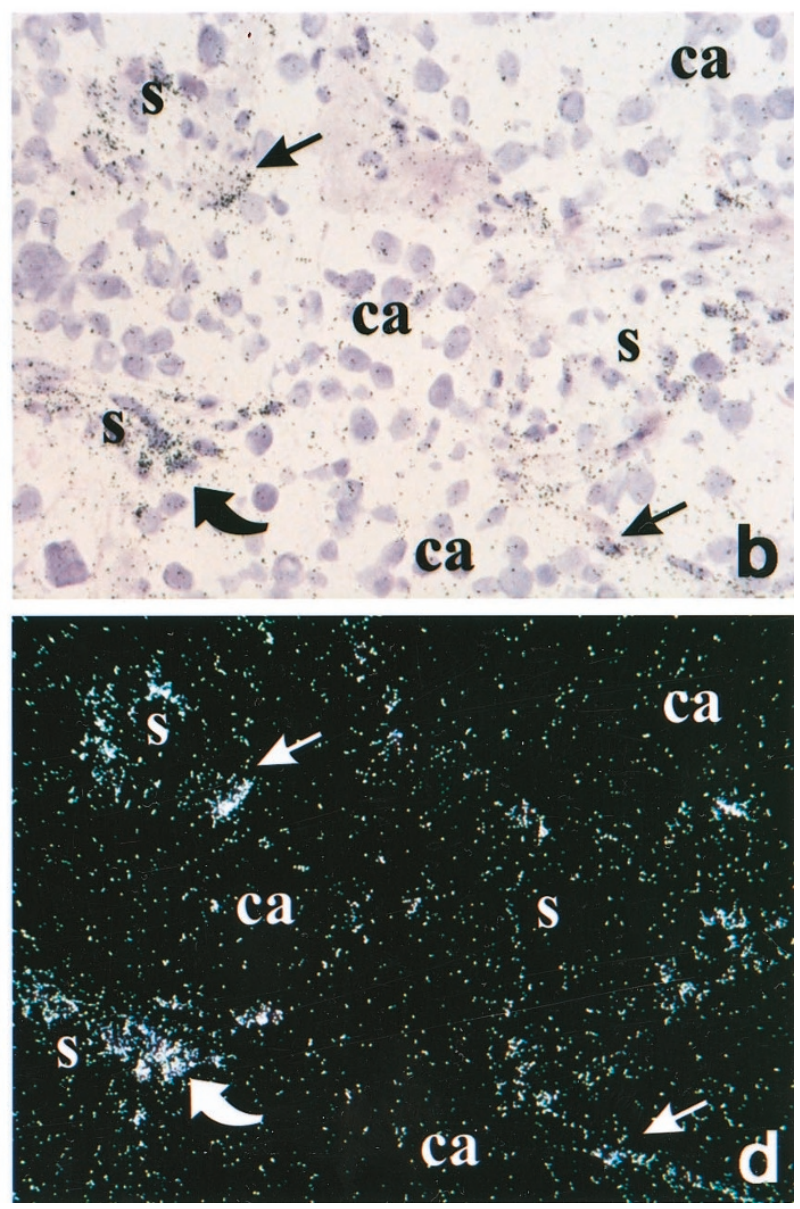


tissue specimens. As it appears from Figure 1, B and $\mathrm{C}$, there was a close correlation between the average relative scores of UPA staining intensity given by three independent observers and the UPA antigen levels measured by ELISA in the corresponding extracts (Spearman rank correlation 0.90, $p<0.02$ ).

The specificity of the UPA immunostaining was also supported by strong similarity between the antigenstaining pattern and the pattern of UPA mRNA expression in fibroblasts that was found in our previous study (Nielsen et al, 1996). This similarity was confirmed when UPA immunostaining and UPA mRNA in situ hybridization were performed on adjacent sections from five invasive ductal carcinomas (Fig. 2B).

\section{Colocalization of uPA and Cell Type Markers}

We have previously found that the uPA mRNA in breast cancer tissue colocalizes with $\alpha$-smooth muscle actin ( $\alpha$-sm-actin) immunoreactivity in fibroblastlike cells that we identified as myofibroblasts (Nielsen et al, 1996). In breast carcinomas, $\alpha$-sm-actin may not only be expressed in myofibroblasts, but also in myoepithelial cells. Myoepithelial cells surround normal glands and ductal carcinoma in situ foci, which may occasionally be present in some of the invasive carcinomas. They are easily recognized by their serrated morphology. In addition, $\alpha$-sm-actin is present in vascular smooth muscle cells in arteries, veins, and larger capillaries (Nielsen et al, 1996; Sappino et al, 1988). We, therefore, only considered $\alpha$-sm-actin immunoreactive cells as myofibroblasts when they were located extravascularly and had a fibroblast-like morphology.

Eight invasive ductal carcinomas were analyzed by immunoperoxidase staining for UPA (pAb2) and $\alpha$-smactin on adjacent sections. The uPA-immunoreactive cells were often colocalized with $\alpha$-sm-actinimmunoreactive cells, which on the basis of their morphology and location were identified as myofibroblasts. These cells were particularly abundant and stained strongly for both proteins in the paracentral areas of the tumors and in the vicinity of cancer cells. In contrast, $\alpha$-sm-actin positive cells assessed as myoepithelial cells or vascular smooth muscle cells were not colocalized with the uPA-stained cells. The colocalization of UPA antigen and $\alpha$-sm-actin was directly studied by confocal double immunofluorescence microscopy as shown in Figure 3. In all of eight cases studied, many fibroblast-like cells were double- stained (arrowheads in Fig. 3, a to c) and we concluded that they represent uPA-immunoreactive myofibroblasts.

As discussed above, it was evident from morphological criteria that UPA immunoreactivity was not confined to fibroblast-like cells, but was also present in macrophage-like cells. In accordance with this finding, the double immunofluorescence for UPA and $\alpha$-sm-actin showed that some of the uPA-positive cells were $\alpha$-sm-actin negative (Fig. 3, a to c, open arrows). The assessment of some of the uPA-positive cells as macrophages was confirmed by confocal double immunofluorescence microscopy with a mAb directed against a macrophage-restricted form of the CD68 molecule (mAb PGM1) (Falini et al, 1993) together with the UPA antibodies. This showed that immunoreactivity for UPA was present in a subpopulation of the CD68-positive macrophages in all of the eight cases of ductal carcinoma that we analyzed in this way (Fig. 3, d to f).

To further identify the uPA immunoreactive cells, which appeared morphologically to be capillary endothelial cells, we stained adjacent sections for UPA and the endothelial cell-specific marker CD31. A colocalization of cells stained for the two proteins confirmed the presence of UPA in some capillary endothelial cells (Fig. 4).

\section{Parameters Influencing uPA Immunostaining}

Because our results are in disagreement with several previously published immunohistochemical studies of uPA localization, we tried to elucidate the influence of some parameters that might have contributed to the differences in the results.

\section{Formalin Fixation}

We first studied the effect of temperature and length of formalin fixation on the UPA immunostaining. Frozen specimens from eight invasive ductal carcinomas were fixed in formalin for 1,8 , or 24 to 32 hours at either $4^{\circ} \mathrm{C}$ or room temperature, before they were paraffin embedded. Sections were stained with polyclonal antibodies to uPA (pAb2) and the relative staining intensities were evaluated as described in "Materials and Methods." The specimens that had been formalin fixed at $4^{\circ} \mathrm{C}$ for 1 and 8 hours displayed a strong and similar staining intensity. Specimens fixed at room temperature showed a similar strong immu-

\section{Figure 2.}

Immunoperoxidase staining of human ductal breast cancer tissue with different uPA antibody preparations and comparison with the localization of uPA mRNA. A, Consecutive adjacent sections, prepared as described in Figure 1, were immunohistochemically stained with polyclonal antibody preparations against uPA (pAb1, 5 $\mu \mathrm{g} / \mathrm{ml}$ ) Panel a, and pAb2 (5 $\mu \mathrm{g} / \mathrm{ml})$ Panel b, with a uPA polyclonal antibody preparation preabsorbed with purified uPA (pAb1 ${ }^{-}(5 \mu \mathrm{g} / \mathrm{ml})$ Panel c, with monoclonal antibodies against uPA (\#394, $40 \mu \mathrm{g} / \mathrm{ml})$ Panel d, and $\beta 10(10 \mu \mathrm{g} / \mathrm{ml})$ Panel e, and with a monoclonal antibody of irrelevant specificity (anti-TNP, $10 \mu \mathrm{g} / \mathrm{ml})$ Panel $\mathrm{f}$. Note that a virtually identical staining pattern is seen with the four anti-uPA antibody preparations. Virtually no staining is seen with the polyclonal antibody preparation after preabsorption with uPA (Panel c) or with the monoclonal negative control antibody (Panel f). B, Three adjacent 8- $\mu \mathrm{m}$ cryostat sections were processed for uPA immunohistochemistry with polyclonal antibodies pAb2 ( $5 \mu \mathrm{g} / \mathrm{ml})$ Panel a, and for in situ hybridization with a uPA mRNA antisense probe (Panels $b$ and $d$ ), and sense probe (Panel $c$ ). The in situ hybridization signal is shown in brightfield (Panel b) and darkfield illumination (Panels $c$ and d). Expression of uPA immunoreactivity and UPA mRNA are seen in stromal cells $(s)$, whereas cancer cells $(c a)$ are negative. No signal is seen with the sense probe (Panel c). Some uPA immunoreactive and UPA mRNA positive cells can be identified on the two adjacent sections (arrows), and a focus with strong uPA immunoreactivity is also strongly positive for uPA mRNA (curved arrow). Note that the 24-hour fixation of the sections for in situ hybridization conserve the cell nuclei better than the 30 -minute fixation of the sections processed for immunohistochemistry. Bars in A: $30 \mu \mathrm{m} ; \mathrm{B}: 40 \mu \mathrm{m}$. 

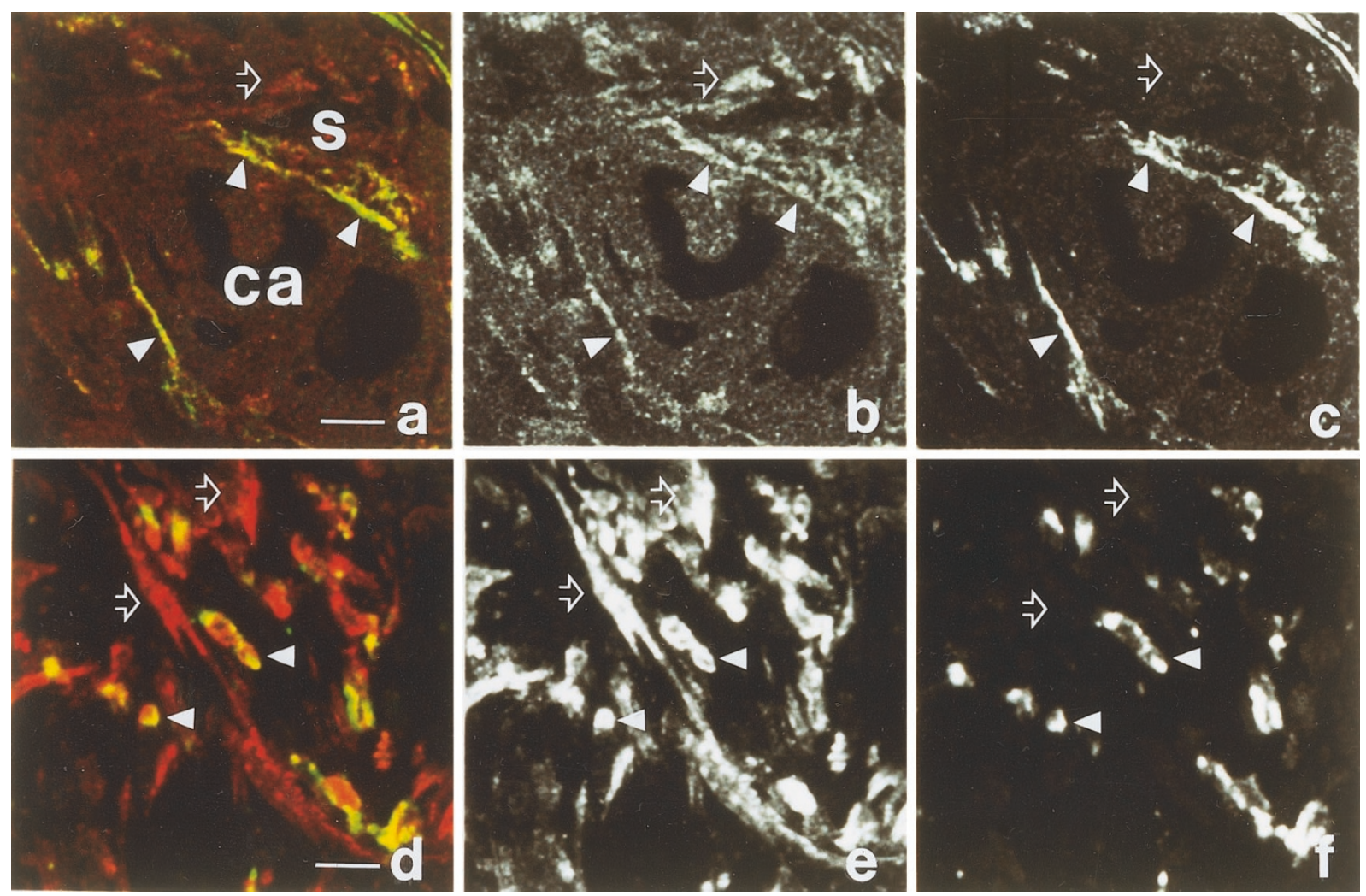

Figure 3.

Double immunofluorescence confocal laser scanning microscopy of human ductal breast cancer tissue for uPA, together with markers of myofibroblasts and macrophages. Sections prepared as described in Figure 1 were incubated with polyclonal antibodies against UPA (pAb1, $2 \mu \mathrm{g} / \mathrm{ml}$ ) together with monoclonal antibodies to either the myofibroblast marker $\alpha$-smooth muscle actin ( $\alpha$-sm-actin, Panels $\mathrm{a}-\mathrm{-}$ ) or the macrophage marker CD68 (Panels $\mathrm{d}-\mathrm{f}$ ). uPA antibodies were detected with Fast Red fluorochrome (red in Panels a and d), whereas $\alpha$-sm-actin and CD68 antibodies were detected with FITC fluorochrome (green in Panels a and d). Double scans of staining for uPA and $\alpha$-sm-actin (Panel a) and for uPA and CD68 (Panel d), and single scans for uPA (Panels b and e), $\alpha$-sm-actin (Panel c), and CD68 (Panel f) are shown. uPA staining colocalizes with $\alpha$-sm-actin staining (yellow color in Panel a) in cells identified as myofibroblasts (indicated by arrowheads in Panels $\mathrm{a}-\mathrm{c}$ ) and with CD68 staining (yellow color in Panel d) in cells identified as macrophages (indicated by arrowheads in Panels d-f). Note that some uPA-positive cells are $\alpha$-sm-actin-negative (open arrow in Panels a-c) and that some uPA-positive cells are CD68-negative (open arrows in Panels $\mathrm{d}$-e). The uPA-positive and CD68-negative fibroblast-like cell indicated by open arrows in Panels $d-f$ are probably myofibroblasts. In Panel a, $s$ indicates a stromal part of the tumor, and $c a$ indicates cancer cells. Bars: Panels a-c, $30 \mu \mathrm{m}$; Panels d-f, $15 \mu \mathrm{m}$.
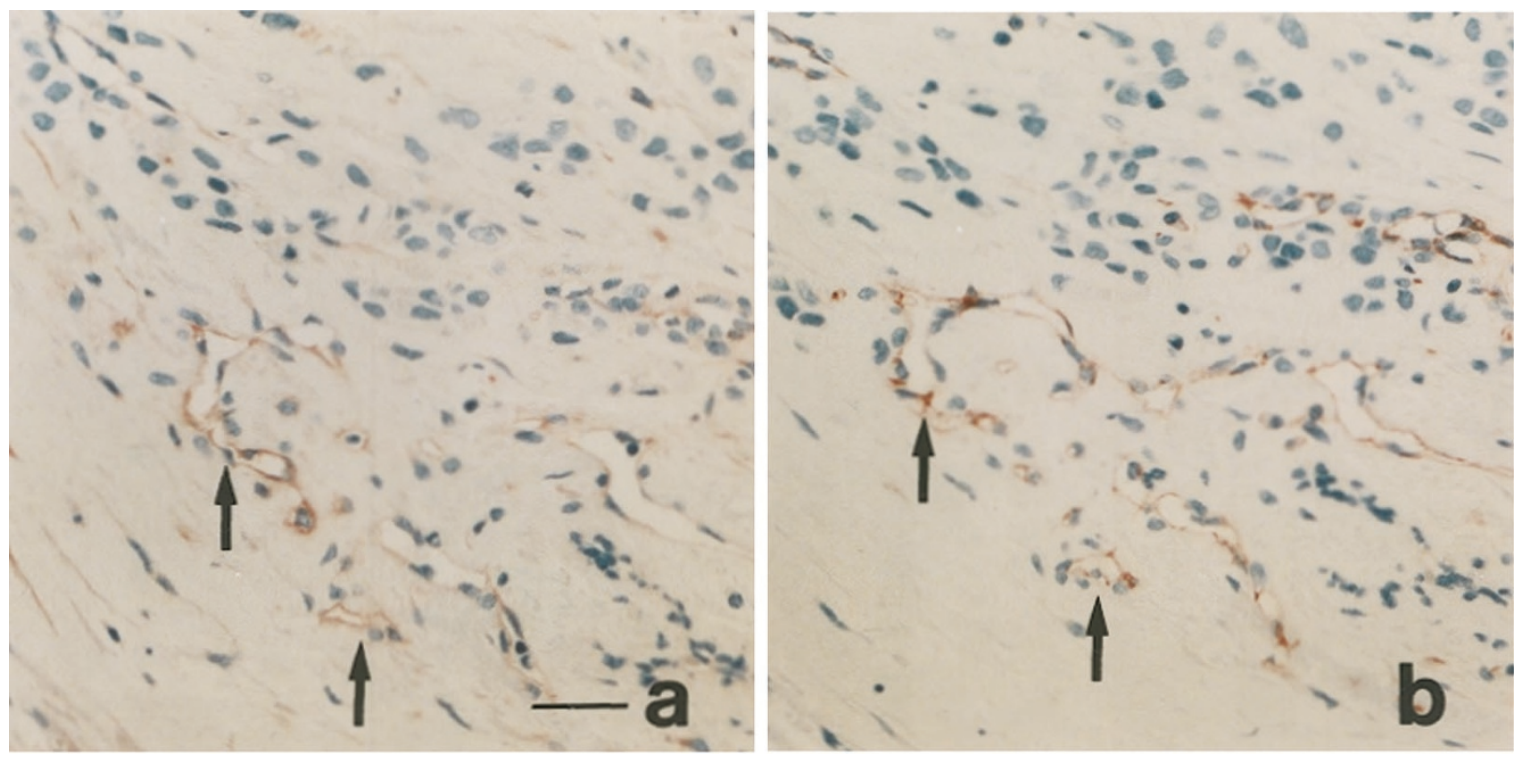

Figure 4.

Immunoperoxidase staining of adjacent sections of human ductal breast cancer tissue for UPA and the endothelial cell marker CD31. Two adjacent sections, prepared as described in Figure 1, were incubated either with polyclonal antibodies against uPA (pAb2, $5 \mu \mathrm{g} / \mathrm{ml}$ ) Panel a, or with a monoclonal antibody against CD31 for the identification of endothelial cells (Panel b). Corresponding capillary structures show immunostaining for both uPA and CD31 (arrows). Bar: $30 \mu \mathrm{m}$. 
nostaining after 1 hour, whereas only weak staining was generated after fixation for 8 hours. No, or only occasional, immunostaining was seen in specimens fixed for 24 to 32 hours at either $4^{\circ} \mathrm{C}$ or at room temperature (Table 1 and Fig. 5). Thus, loss of uPA staining can be caused by overfixation, resulting from either high temperature or prolonged fixation time.

\section{Trypsin Predigestion}

Proteolytic digestion is used as a general pretreatment to demask epitopes in immunohistochemistry (Stern- berger, 1979). We found that the short trypsin predigestion (6 minutes) we routinely use was essential for retrieving UPA immunoreactivity in the standard formalin-fixed and paraffin-embedded specimens (Fig. 5, f to g). However, in specimens that were fixed for 24 to 32 hours at either $4^{\circ} \mathrm{C}$ or room temperature, the predigestion did not retrieve any or retrieved only faint UPA immunoreactivity, even after prolonged digestion (data not shown). Prolonged trypsin digestion ( $>10$ minutes) of the standard formalin-fixed and paraffin-embedded specimens
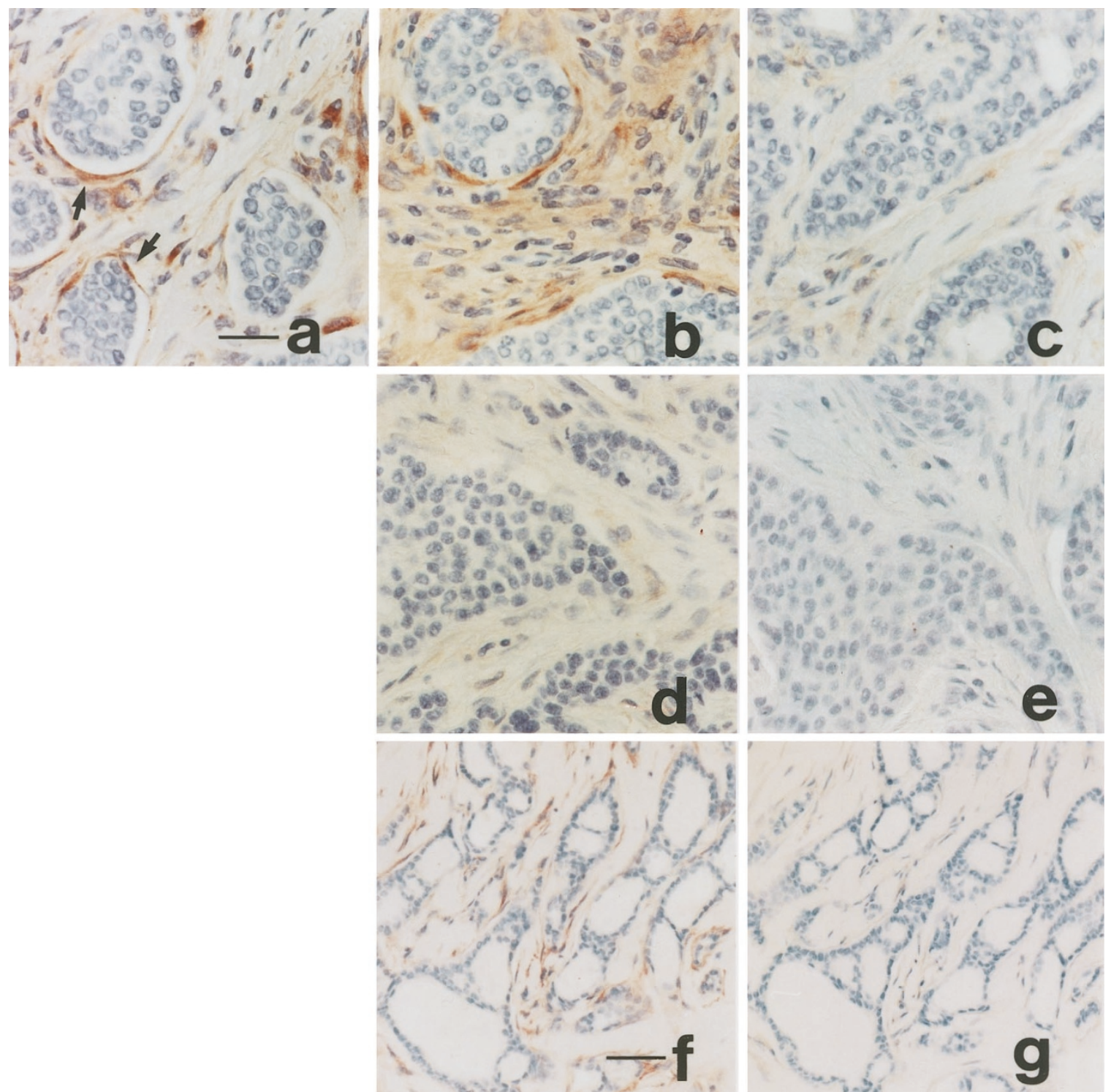

Figure 5 .

Influence of fixation time, fixation temperature, and trypsin treatment on uPA immunoperoxidase staining of paraffin-embedded specimens of human ductal breast cancer tissue. Specimens were formalin fixed at $4^{\circ} \mathrm{C}$ for 1 hour (Panels a, $f, g$ ), 8 hours (Panel b), and 24 hours (Panel c) or at room temperature for 8 hours (Panel d) and 24 hours (Panel e), and immunostained with polyclonal antibodies to uPA (pAb2, $5 \mu \mathrm{g} / \mathrm{ml}$ ). Most sections were briefly predigested with trypsin (Panels a-f), although this treatment was omitted for one of the sections (Panel g). Note that when fixation was performed at $4^{\circ} \mathrm{C}$, the immunostaining produced is strong in specimens fixed for 1 hour and 8 hours (Panels a, b, f), but barely detectable after fixation for 24 hours (Panel c). At room temperature fixation for 8 hours results in weak staining (Panel d), and fixation for 24 hours results in no immunostaining (Panel e). When trypsin predigestion is omitted, there is little or no uPA immunostaining, even of sections formalin fixed for 1 hour at $4^{\circ} \mathrm{C}$ (Panel g). Note that the immunostaining in all sections appears in the stroma and not in the cancer cells and that the strongest immunostaining is present in the fibroblast-like cells surrounding the tumor cell islands (arrows in Panel a). Bars in Panels a-e: $30 \mu \mathrm{m}$; Panels $\mathrm{f}-\mathrm{g}, 50 \mu \mathrm{m}$. 
Table 1. Influence of Fixation Time and Temperature on $\mu P A$ Immunoperoxidase Staining of Paraffin-Embedded Specimens from Human Ductal Breast Cancer Tissue ${ }^{a}$

\begin{tabular}{ccc}
\hline & \multicolumn{2}{c}{$\begin{array}{c}\text { Relative staining intensities } \\
\text { (number of specimens) }\end{array}$} \\
\cline { 2 - 3 } Time $(\mathrm{h})$ & $4^{\circ} \mathrm{C}^{c}$ & Room temperature $^{c}$ \\
\hline 1 & $3+(8)^{d}$ & $3+(4)$ \\
8 & $3+(2)$ & $1+(2)$ \\
$24-32$ & $0(2)$ & $0(8)$ \\
\hline
\end{tabular}

$\mu \mathrm{PA}$, urokinase plasminogen activator.

${ }^{a}$ Specimens were formalin fixed for 1,8 , or $24-32 \mathrm{~h}$ at $4^{\circ} \mathrm{C}$ or room temperature, paraffin embedded, and then stained with polyclonal anti-uPA IgG (pAb2, $5 \mu \mathrm{g} / \mathrm{ml}$ ). Relative staining intensities were scored as specified in "Material and Methods." Specimens fixed for 1 and $8 \mathrm{~h}$ at $4^{\circ} \mathrm{C}$, and $1 \mathrm{~h}$ at room temperature, had an almost equal intensity, whereas the specimens fixed for 24-32 $\mathrm{h}$ at either temperature showed little or no staining (see also Fig. 5).

${ }^{b} 3+=$ strong, $2+=$ moderate, $1+=$ weak, $0=$ no or only occasional staining.

${ }^{c}$ Fixation temperatures.

${ }^{d}$ Defined as $3+$

was associated with reduced uPA immunoreactivity and tissue morphology.

\section{Paraffin Embedding}

To test whether the paraffin embedding used in our standard procedure had any effect on the uPA immunostaining pattern, we compared the staining pattern in paraffin sections with that in cryostat sections from specimens of the same tumor. In this experiment, we analyzed specimens from three cases of ductal carcinoma with the monoclonal $\beta 10$ antibody, the polyclonal antibodies pAb1, and the uPA-preabsorbed antibody preparation $\mathrm{pAb} 1^{-}$. In all three cases, $\beta 10$ and pAb1 showed stromal staining in paraffin sections with a similar pattern but with slightly stronger intensity than that found in the corresponding cryostat sections (Fig. 6). Virtually no staining was seen in any of the three cases in either paraffin or cryostat sections with the preabsorbed preparation $\left(\mathrm{pAb}^{-}{ }^{-}\right)$. Thus, under these conditions, paraffin embedding does not change the uPA immunostaining pattern but may slightly increase the intensity.

\section{Different uPA Antibodies}

To further test the specificity of different antibodies directed against UPA, we tested four additional mAb against uPA (clones 5, 6, \#377, and \#394) by immunoperoxidase staining of four cases of invasive ductal carcinoma, using our standard procedure with antibody concentrations ranging from 10 to $40 \mu \mathrm{g} / \mathrm{ml}$. Each of these four UPA-antibodies have previously been used in immunohistochemical studies of UPA in breast cancer (Carriero et al, 1994; Christensen et al, 1996; Del Vecchio et al, 1993; Jänicke et al, 1991; Jankun et al, 1993; Kennedy et al, 1998; Sumiyoshi et al, 1991). We also included two additional control mAb of irrelevant specificity (anti-hirudin and antiovalbumin). With two exceptions, it was found that the two negative control mAb of irrelevant specificity gave no staining, whereas all four $\mathrm{UPA}^{-}$antibodies gave stromal staining patterns, which agrees with the results obtained with the three initially used UPA antibody preparations, although there were moderate differences in the staining intensities (Table 2). The first exception was that antibody \#394, used at a high concentration $(40 \mu \mathrm{g} / \mathrm{ml})$, weakly stained cancer cells in addition to stromal cells in some of the tumors (not shown), whereas in other tumors it only stained the stromal compartment (Fig. 2A, Panel d). The second exception was that $40 \mu \mathrm{g} / \mathrm{ml}$ of the control mAb raised against TNP, gave a cancer cell staining (but no stromal staining), which was similar to the result obtained with mAb \#394 in the same tumors.

\section{Detergent Wash}

We routinely use the nonionic detergent Triton X- 100 in the washing buffers in our standard immunoperoxidase staining procedure to reduce the nonspecific absorption of antibodies (Hartmann et al, 1972; Juhl et al, 1984; Larsson, 1981; Larsson et al, 1984; Seppa and Jarvinen, 1979; Sternberger, 1979). Because detergent wash may not have been used in some of the studies in which uPA immunostaining has been found in breast cancer cells (Jänicke et al, 1991; Jankun et al, 1993; Sumiyoshi et al, 1991), we tested the effect of omission of detergent. These experiments were done with paraffin sections that had been formalin fixed for 24 hours at room temperature to mimic the conditions that exist for routine stainings in pathology departments and in the above-cited UPA staining studies. Furthermore, we used the same uPA mAb (\#394) as used in those studies. Under these conditions we observed staining of cancer cells (but not of stromal cells) with $10 \mu \mathrm{g} / \mathrm{ml}$ of the \#394 uPA antibody in three of four different invasive ductal carcinomas studied in this way (Fig. 7a). A similar staining was found in the same three cases with the same concentration of the anti-TNP control antibody when the detergent wash was omitted (Fig. 7c). No staining of either cancer cells or stromal cells was seen when staining with the \#394 and anti-TNP antibodies were done in parallel under conditions that were identical except for the addition of detergent to the washing buffers (Fig. 7, b and d). To examine whether staining of cancer cells could be generated by other mAb, we tested uPA mAb clones 5 and 6 as well as anti-hirudin and anti-ovalbumin antibodies $(10 \mu \mathrm{g} / \mathrm{ml})$, using detergent-free washing of these strongly fixed sections. Whereas anti-uPA clones 5 and 6 and anti-ovalbumin in all 4 cases showed no staining, the anti-hirudin antibody did stain cancer cells in a similar way as the \#394 and anti-TNP antibodies (not shown).

\section{Discussion}

We found uPA immunostaining in tumor tissue from all of 25 cases of ductal mammary cancer. A virtually identical staining pattern was obtained with a mouse monoclonal and two different rabbit polyclonal uPA 

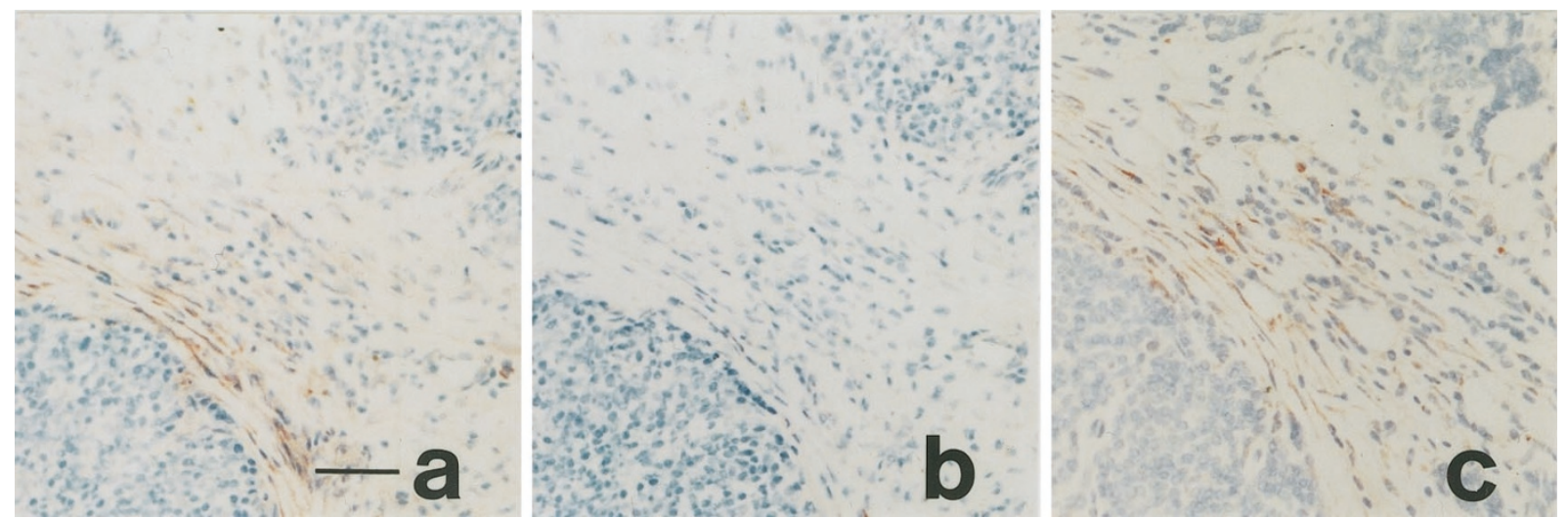

Figure 6.

UPA immunoperoxidase staining of cryostat sections and paraffin sections from the same sample of human ductal breast cancer tissue. Cryostat sections (Panels $\mathrm{a}, \mathrm{b})$ were stained with polyclonal antibodies against uPA (pAb1, $10 \mu \mathrm{g} / \mathrm{ml}$ ) Panel a, and the same antibody preparation preabsorbed with purified immobilized uPA (pAb1- $10 \mu \mathrm{g} / \mathrm{ml}$ ) Panel b. Paraffin sections were incubated with the polyclonal uPA antibodies (pAb1, $5 \mu \mathrm{g} / \mathrm{ml}$ ) Panel c. A strong signal is seen in the tumor stroma in both cryostat and paraffin sections (Panels a, c). No staining is observed in the cancer cells. Absorption with uPA completely abolished the staining (Panel b). Bar: $50 \mu \mathrm{m}$.

antibody preparations. No staining was observed when the monoclonal uPA antibody was replaced with a $\mathrm{mAb}$ of the same IgG subtype but of irrelevant specificity or when the polyclonal uPA antibodies were replaced with a nonimmune rabbit immunoglobulin preparation or with one of the polyclonal uPA antibody
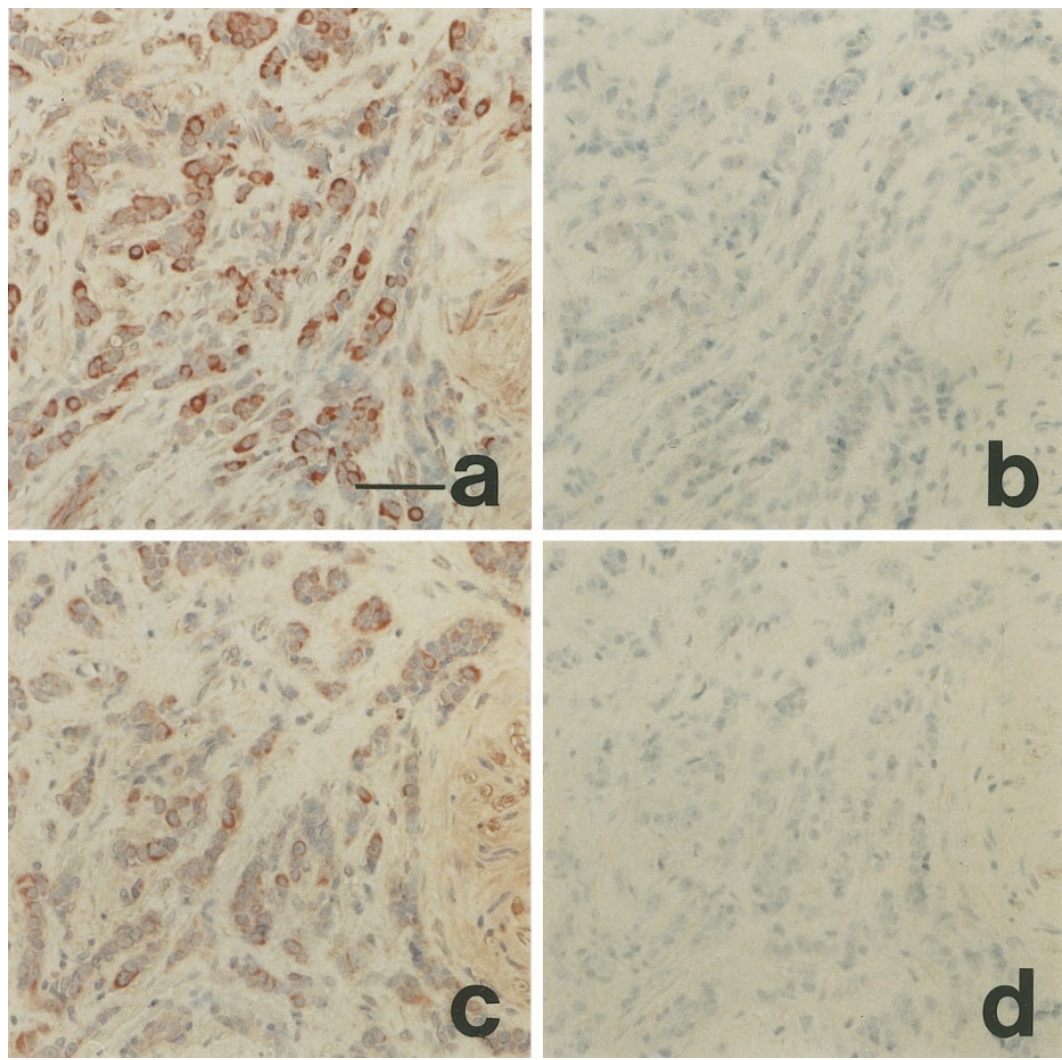

\section{Figure 7.}

Effect of detergent in washing buffer on staining of prolonged formalin-fixed human ductal breast cancer tissue with the \#394 monoclonal uPA antibody and a control tri-nitro-phenyl (TNP) antibody. Sections from paraffin-embedded specimens, fixed for 24 hours at room temperature, were incubated with the \#394 monoclonal antibody against uPA (10 $\mathrm{g} / \mathrm{ml}$, Panels a, b) or the negative control monoclonal antibody against TNP (10 $\mu \mathrm{g} / \mathrm{ml}$, Panels c, d), and these were immunohistochemically processed without (Panels a, c) or with (Panels b, d) detergent ( $0.5 \%$ Triton X-100) in the washing buffer. No staining is seen with \#394 and anti-TNP using detergent containing washing buffer (Panels $b, d$ ), whereas staining of cancer cells is observed with both \#394 and anti-TNP when detergent is omitted from the washing buffer (Panels a, c). Note that, with the prolonged fixation used in this experiment, immunostaining for UPA is not found in the stromal cells of detergent-washed sections. This lack of specific uPA staining of prolonged formalin-fixed tissue is in agreement with results obtained with other uPA antibody preparations (Figure 5 and Table 1). In contrast, the standard procedure, including fixation for 1 hour at $4^{\circ} \mathrm{C}$ and detergent wash, results in staining that is confined to stromal cells when $40 \mu \mathrm{g} / \mathrm{ml}$ of the \#394 antibody is used (Figure 2B, Panel d). As discussed in the text, we consider the staining of the cancer cells shown in Panel a to be nonspecific. Bar: $50 \mu \mathrm{m}$. 
preparations that had been preabsorbed with a purified UPA preparation. We therefore concluded that the immunostaining represented genuine uPA immunoreactivity. This conclusion was further supported by (a) a close correlation between the intensity of the UPA immunostaining of tissue sections and the UPA protein content measured by ELISA in extracts of adjacent specimens and (b) by a very similar pattern of UPA immunostaining and UPA mRNA expression found on adjacent sections. In all 25 cases of ductal mammary cancer, uPA immunoreactivity was found in stromal cells, whereas cancer cells were only immunoreactive in 3 of the cases, and in these cases only a small subpopulation of the cancer cells were uPA-immunoreactive.

By morphological criteria we assessed the uPApositive stromal cells in all cases to include some fibroblasts and macrophages and also, in approximately half of the cases, some capillary endothelial cells. This cell identification was verified by studies of the colocalization of UPA and markers for these cell types. Staining of adjacent sections and confocal laser scanning double immunofluorescence microscopy thus showed colocalization of UPA and $\alpha$-sm-actin, which in breast cancer tissue is found in myofibroblasts, occasional myoepithelial cells, and vascular smooth muscle cells (Nielsen et al, 1996; Sappino et al, 1988). Based on morphological criteria, we determined that the cells positive for UPA and $\alpha$-sm-actin were not myoepithelial cells, and their extravascular location showed that they were not vascular smooth muscle cells. We therefore concluded that they were myofibroblasts, in good agreement with their spindleshaped morphology and their preferential localization adjacent to cancer cell formations. The colocalization studies, however, also showed that not all myofibro- blasts expressed detectable amounts of uPA. Similar studies of colocalization of UPA and the macrophage marker CD68 verified that some of the uPA-positive cells were tumor-infiltrating macrophages. But, again, it was only a subpopulation of the macrophages that expressed detectable uPA immunoreactivity. Staining of adjacent sections for UPA and the endothelial cell-specific marker CD31 confirmed that some capillary endothelial cells were UPA immunoreactive.

Our results are in agreement with those of Visscher et al $(1993,1995)$ and Kennedy et al (1998), who found that UPA immunostaining was mainly located in stromal cells in breast cancer tissue. Visscher et al (1993, 1995) described the uPA-positive cells as stromal cells, including endothelial cells. Kennedy et al (1998) described positive stromal cells as fibroblasts, myofibroblasts, and macrophage-like cells, and with double staining they identified uPA-positive macrophages but no uPA-positive vessels. In contrast, our results strongly disagree with those of Jänicke et al (1991), Sumiyoshi et al (1991), Jankun et al (1993), Del Vecchio et al (1993), and Damjanovich et al (1994), who all found that UPA is exclusively or mainly located in cancer cells, and our results also disagree with those reported by Costantini et al $(1991,1996)$, Carriero et al (1994), Christensen et al (1996), and Dublin et al (2000), who found substantial staining of both cancer cells and stromal cells.

We found that a lack of staining of stromal cells can be due to prolonged formalin fixation. Thus, a strong and specific uPA staining found in tissue that had been fixed for 1 hour at either $4^{\circ} \mathrm{C}$ or room temperature, became weak when the tissue had been fixed for 8 hours at room temperature and was undetectable when the tissue had been fixed for 24 to 32 hours at either $4^{\circ} \mathrm{C}$ or room temperature. Although fixation

Table 2. Relative Intensities of Immunostaining of Human Ductal Breast Cancer Samples Obtained with Different uPA and Control Antibody Preparations ${ }^{a}$

\begin{tabular}{|c|c|c|c|}
\hline Antibody preparation ${ }^{b}$ & $\begin{array}{c}\text { Number of } \\
\text { samples }\end{array}$ & $\begin{array}{l}\text { IgG concentration } \\
(\mu \mathrm{g} / \mathrm{ml})\end{array}$ & $\begin{array}{l}\text { Relative staining } \\
\text { intensity }{ }^{c}\end{array}$ \\
\hline mAb 5 & 4 & 40 & $1+$ \\
\hline mAb 6 & 4 & 40 & $2+$ \\
\hline $\mathrm{mAb} \beta 10$ & 5 & 10 & $3+$ \\
\hline mAb \#377 & 4 & 40 & $2+$ \\
\hline mAb \#394 & 2 & 10 & 0 \\
\hline mAb \#394 & 4 & 40 & $2+^{d}$ \\
\hline mAb TNP* & 5 & 10 & 0 \\
\hline mAb TNP* & 4 & 40 & $0^{d}$ \\
\hline mAb hirudin* & 2 & 10 & 0 \\
\hline mAb ovalbumin* & 2 & 10 & 0 \\
\hline pAb1 & 5 & 5 & $3+$ \\
\hline pAb2 & 5 & 5 & $3+^{e}$ \\
\hline $\mathrm{pAb} 1^{-\star}$ & 5 & 5 & 0 \\
\hline Nonimmune rabbit $\lg G^{*}$ & 5 & 5 & 0 \\
\hline
\end{tabular}

\footnotetext{
${ }^{a}$ Specimens were formalin fixed for $1 \mathrm{~h}$ at $4^{\circ} \mathrm{C}$, paraffin embedded, and stained, using standard procedures. In all cases the staining intensity was evaluated by comparison with the staining of adjacent or near-adjacent sections performed in parallel with pAb2 ( $\mu \mathrm{g} / \mathrm{ml})$, which was rated as $3+($ see "Materials and Methods").

${ }^{b}$ Control antibodies are labeled with asterisks. All other antibodies are directed against uPA.

${ }^{c}$ Relative staining intensity: $3+=$ strong, $2+=$ moderate, $1+=$ weak, $0=$ no or only occasional staining.

${ }^{d}$ Some staining of cancer cells observed in some tumors is considered non-specific and not included in the rating (see text)

${ }^{e}$ Defined as $3+$.
} 
time is not specified in most of the studies that found no stromal uPA-staining, it is likely that several of them have used prolonged formalin fixation, because it is routinely used in many pathology departments, and this factor may be important for the differences in staining results.

Another factor we found important for detection of UPA immunoreactivity was proteolytic treatment of sections before incubation with the UPA antibodies. In our standard staining procedure, we used trypsin for predigestion (Sternberger, 1979). When the predigestion was omitted, we found virtually no uPA staining, in contrast to a strong and specific UPA staining of adjacent sections that had been trypsin treated. In several of the reports showing a lack of, or only weak, UPA staining in stromal cells, it is not indicated whether or not proteolytic retrieval of immunoreactivity has been used, and this parameter may therefore also have contributed to the different findings.

The immunostaining could also be influenced by the paraffin embedding used before sectioning. We compared the UPA staining of paraffin sections with that of cryostat sections but found no difference in the staining pattern, although the staining intensity was slightly weaker in the cryostat sections. In all the cited UPA staining studies, either paraffin or cryostat sections have been used. It is therefore not likely that differences in embedding procedure have played any major role in producing the differences in results.

To evaluate the possible importance of the use of different uPA antibody preparations in different studies, we tested four $m A b$ in addition to the single monoclonal and two polyclonal antibodies we initially used. Using our standard conditions, we found stromal staining with all of the antibody preparations, although the staining intensities and the antibody concentrations needed to obtain staining varied. It is therefore not likely that the discrepancies in stromal staining between our study and the other studies are to any large extent due to the use of different UPA antibodies.

We found that the staining of cancer cells was influenced by the antibody preparation used. Under our standard conditions, we found that the mAb \#394 was alone among the seven UPA antibody preparations tested in showing diffuse cancer cell staining in some tumors when used at a high concentration (40 $\mu \mathrm{g} / \mathrm{ml})$. This concentration was required for the antibody to give appreciable amounts of stromal cell staining. However, under the same conditions, similar cancer cell staining, but no stromal staining, was obtained when the same tumors were stained with a monoclonal TNP-antibody of the same murine IgG subclass, and we therefore concluded that the cancer cell staining obtained with antibody \#394 under these conditions is nonspecific. Antibody \#394 has been used in many of the studies showing cancer cell staining. The use of different antibody preparations is therefore likely to have contributed substantially to the differences in the staining of cancer cells.

We further found that cancer cell staining with the \#394 antibody was strongly enhanced when we omit- ted the addition of detergent to washing buffers, which can be used to reduce nonspecific binding of antibodies (Hartmann et al, 1972; Juhl et al, 1984; Larsson, 1981; Larsson et al, 1984; Seppa and Jarvinen, 1979; Sternberger, 1979). Without detergent we found that a low concentration of the \#394 antibody-so low that it did not give stromal staining $(10 \mu \mathrm{g} / \mathrm{ml})$ - gave cancer cell staining in three of four cases that had been formalin-fixed for 24 hours at room temperature. Thus, under these conditions, we obtained staining of cancer cells and no staining of stromal cells, as has also been reported in many previous studies. It should be noted however that similar cancer cell staining was also obtained under these conditions with two different negative control mAb of irrelevant specificity, so that it may be reasonably concluded that the staining we obtained with the \#394 mAb was not specific for uPA. In these experiments neither the \#394 antibody nor the negative control antibodies produced staining of cancer cells when detergent was added to the washing buffers. In most of the reports on uPA staining of cancer cells, it is not indicated whether detergent was used in the immunohistochemical procedure. It is, therefore, not clear whether this factor has contributed to the different staining patterns.

We conclude that the conflicting results reported on the immunohistochemical localization of uPA in breast cancer tissue may be due to the use of different antibodies and different procedures with respect to fixation conditions, proteolytic retrieval, and detergent wash. It is, however, not possible to determine the extent to which each of these parameters may have influenced the individual studies, because sufficiently detailed information on the methods used is often lacking.

The in situ hybridization localization of UPA mRNA in stromal cells found in this study is consistent with our previous in situ hybridization study, in which 26 of 28 cases of ductal breast carcinoma showed distinct UPA mRNA signals in fibroblasts, whereas only 1 case showed a signal in cancer cells (Nielsen et al, 1996). In that study, identical results were obtained with two nonoverlapping antisense RNA-probes, whereas no signals were found with the corresponding sense RNA probes, and immunostaining for a panel of stromal cell markers identified the UPA mRNA expressing cells as myofibroblasts. It is noteworthy that two cases of breast cancer with squamous cell differentiation included in the previous study showed uPA mRNA expression in cancer cells in contrast to the findings in the ductal cancers (Nielsen et al, 1996). Wolf et al (1993) also found that uPA mRNA is almost exclusively expressed in fibroblasts in ductal mammary cancer, whereas Escot et al (1996) with one antisense mRNA probe found a weak signal in both cancer cells and stromal cells in breast adenocarcinomas of unspecified subtype. The reason for the discrepancy in cancer cell expression between this latter study and the three other in situ hybridization studies is unknown.

Our finding of UPA protein in macrophages is surprising in view of the lack of detectable uPA mRNA in these cells (Nielsen et al, 1996). This may indicate that 
the UPA protein found in the macrophages has actually been produced and secreted by the myofibroblasts and then subsequently become bound to UPAR, which is mainly located on macrophages in breast cancer tissue (Bianchi et al, 1994; Pyke et al, 1993). It is, however, also possible that UPA mRNA is actually present in macrophages, but in amounts below the detection limit of the in situ hybridization technique used in our previous study. The localization of UPA protein in capillary endothelial cells also seems to contradict the previously reported lack of UPA mRNA in these cells (Nielsen et al, 1996). Again, this may indicate that the UPA found in the endothelial cells is produced by the myofibroblasts and subsequently has become bound to the UPAR, which is expressed by some endothelial cells in breast cancer tissue (Bianchi et al, 1994). In this respect it is also relevant that another UPA binding protein, the inhibitor PAl-1, likewise is expressed by some endothelial cells in breast cancer (Bianchi et al, 1995; Pappot et al, 1995). It is also possible that UPA mRNA is present in endothelial cells at levels below the detection limit. A clarification of the possible colocalization of UPA with UPAR and PAl-1 will require further confocal immunofluorescence studies.

Our present findings add to the general view that stromal cells are strongly involved in the generation and regulation of extracellular proteolysis during cancer invasion (Danø et al, 1993; Hewitt and Danø, 1996; Johnsen et al, 1998; Werb, 1997). This stromal cell involvement includes both the uPA system and the matrix metalloproteases. The pattern of expression of individual components of protease systems is usually very similar in different cases of the same type or subtype of cancer, whereas it often varies between different types of cancer. The preferential expression of UPA in fibroblasts, UPAR in macrophages, and PAl-1 in endothelial cells that is observed in ductal mammary carcinoma is similar to the pattern seen in colon cancer, where uPA is located in fibroblast-like cells (Grøndahl-Hansen et al, 1991; Pyke et al, 1991b), PAl-1 in endothelial cells (Pyke et al, 1991a), and UPAR in macrophages, and, unlike ductal mammary carcinoma, usually also in a subpopulation of the cancer cells (Pyke et al, 1991a, 1994). In contrast, in squamous skin carcinoma, UPA, UPAR, and PAI-1 are all mainly expressed by the cancer cells (Hewitt and Danø, 1996). The matrix metalloproteases, gelatinase A and stromelysin-3, are expressed by fibroblasts in all three types of cancer discussed here. Gelatinase B is expressed by macrophages in all three cancer types, and in squamous cell skin cancer, also in some cancer cells (Hewitt and Danø, 1996; Johnsen et al, 1998).

It could be argued that the stromally produced components of protease systems have no functional role in tumor biology or even that they may be a part of the host defense mechanism. However, several lines of evidence indicate that these components play a role in tumor progression. In polyoma middle T-induced mouse mammary carcinoma, as in human ductal mammary carcinoma, UPA mRNA is found in fibroblast-like stromal cells (Bugge et al, 1998). In plasminogen-deficient mice, metastasis of this experimental tumor is delayed, indicating that plasmin generation by uPA produced by these stromal cells facilitates metastasis (Bugge et al, 1998).

That stromal cell-produced components of protease systems have substantial effects on cancer progression is also strongly supported by prognostic studies of cancer patients. Such studies show that high levels of the components involved in extracellular matrix degradation measured in the tumor tissue or blood in many types of cancer are associated with poor prognosis, apparently regardless of whether these components are expressed in stromal cells or in cancer cells (Brünner et al, 2000). It is particularly noteworthy that the high levels of UPA in human breast cancer tissue extracts, which as demonstrated in the present study mainly comes from stromal cells, are consistently associated with poor prognosis (Brünner et al, 2000; Duffy et al, 1990; Grøndahl-Hansen et al, 1993). In accordance with this statement, Dublin et al (2000) recently reported that the uPA staining they found associated with fibroblastic cells tended to be associated with shorter time to relapse, whereas this was not the case for the staining they found associated with cancer cells (Dublin et al, 2000).

Cancer cells thus appear to recruit stromal cells to produce components of protease systems in a process that promotes tumor progression (Danø et al, 1993; Johnsen et al, 1998). The mechanisms involved in this recruitment are little known, but must involve some form of signaling between the cancer cells and the stromal cells. The phenomenon of stromal expression of molecules important for cancer progression has particularly been studied in relationship to matrixdegrading protease systems, but it is likely to reflect a more general involvement of stromal cells in tumor biology, ie, that the stromal cells contribute not only to invasion and metastasis but also to other capabilities crucial for cancer progression, such as tumor growth (Chung, 1991; Hanahan and Weinberg, 2000; Kerbel, 1995; Noel et al, 1993).

We have previously suggested that a requirement of stromal cells for cancer progression may have profound implications for our understanding of crucial aspects of cancer biology (Danø et al, 1993; Johnsen et al, 1998). Recruitment of a distinct group of stromal cells could thus be critical for the development of a single cancer cell that has migrated from the primary tumor to another tissue into a progressing metastasis. This recruitment process may contribute substantially to the long latency in occurrence of metastases that is seen in many types of human cancer. Furthermore, the selectivity of the metastasis of some types of tumors for specific organs or tissues (Tarin, 1992) may reflect the chances of a successful stromal cell recruitment, which depends on the types of cells that are available at the new site.

Similarly, recruitment of stromal cells may play a crucial role in carcinogenesis. It may, therefore, not be sufficient for a cell to acquire the characteristics of a cancer cell; recruitment of the appropriate combina- 
tion of stromal cells may also be needed to form an invasive tumor, and this recruitment process may contribute substantially to the long latency typical of carcinogenesis (Johnsen et al, 1998). Experimental support for this hypothesis was recently reported by Coussens et al (2000), who found that skin carcinogenesis, which is impaired in gelatinase B-deficient mice, can be restored by gelatinase $B$ supplied by transplanted bone marrow cells from normal mice.

The involvement of specific types of stromal cells in cancer progression may form the basis for new therapeutic approaches. The uPA-expressing myofibroblasts may thus be a useful target for the treatment of breast cancer, a distinct advantage being that these nonmalignant cells are less prone to develop resistance than the genetically unstable cancer cells (Danø et al, 1993).

\section{Materials and Methods}

\section{Antibodies}

The following mouse monoclonal antibodies (mAb) to human UPA were used: clones $5,6, \beta 10, \# 377$, and \#394. Clones 5 and 6 have been described previously (Grøndahl-Hansen et al, 1987; Nielsen et al, 1986; Rosenquist et al, 1993). Clone $\beta 10$ was a gift from Dr. J. Grøndahl-Hansen (Danish Veterinary Laboratory, Copenhagen, Denmark). Clones \#377 and \#394 were purchased from American Diagnostica Inc. (Greenwich, Connecticut). A polyclonal IgG anti-uPA preparation (pAb1) was prepared from rabbits immunized with uPA (purified from human urine) and absorbed with human plasma proteins (Grøndahl-Hansen et al, 1988; Kristensen et al, 1984). This preparation was divided into two parts; one part was passed through a column with immobilized bovine serum albumin (pAb1), and the other part was passed through a column with immobilized UPA and was used as a negative control antibody preparation $\left(\mathrm{pAbl}^{-}\right)$. Another polyclonal rabbit Ig anti-uPA preparation, which had been absorbed with human plasma proteins (pAb2), was a gift from Marianne Nielsson (DAKO A/S, Glostrup, Denmark). Negative control mAb to 2,4,6-trinitrophenyl (TNP) hapten, ovalbumin, and hirudin were obtained from the State Serum Institute, Copenhagen, Denmark. mAb recognizing CD31 (clone JC/70A), $\alpha$-sm-actin (clone 1A4), and CD68 (clone PG-M1) were purchased from DAKO. The ABC Kit (K492) for detection of primary antibodies, streptavidin conjugated alkaline phosphatase (D396), and FITC-conjugated goat anti-mouse IgG (F479) were also obtained from DAKO.

\section{Tissues and Fixation}

Tissue specimens with an approximate size of $3 \times 10$ $\times 10 \mathrm{~mm}$ were obtained from 25 cases of primary invasive ductal breast carcinoma (6 Grade I, 14 Grade II, and 5 Grade III, according to Bloom and Richardson, 1957) and 6 cases of primary lobular breast carcinoma. Within 30 minutes after surgical extirpation, the specimens were frozen in isopentane/dry-ice and stored at $-80^{\circ} \mathrm{C}$. As standard procedure for UPA immunohistochemistry, the frozen specimens were thawed at $4^{\circ} \mathrm{C}$ for 10 minutes, fixed in neutral buffered $4 \%$ formalin for 1 hour at $4^{\circ} \mathrm{C}$, and subsequently dehydrated/fixed in ethanol and paraffin embedded. This combination of short-term formalin fixation and ethanol fixation/dehydration of the relatively small tissue specimens resulted in paraffin samples with excellent tissue morphology and had no apparent differential effect on UPA immunoreactivity throughout the tissue sections. In some experiments, cryostat sectioning and/or a different fixation temperature and time were used as indicated. The tumor specimen sampling was in accordance with permission provided by the Regional Scientific-Ethical Committee for Copenhagen and Frederiksberg, Denmark (Journal No. KF 01-456/93).

\section{Immunohistochemistry}

The following standard procedures were used, except where otherwise indicated.

Paraffin sections. Paraffin sections $(5 \mu \mathrm{m})$ were deparaffinized for 20 minutes with coconut-oil at $60^{\circ} \mathrm{C}$ or with xylene at room temperature and hydrated through ethanol/water dilutions. Proteolytic predigestion was performed with $0.025 \%$ trypsin (Sigma, St. Louis, Missouri) in $50 \mathrm{~mm}$ Tris- $\mathrm{HCl}, \mathrm{pH}$ 7.6, containing $0.1 \% \mathrm{CaCl}_{2}$ for 6 minutes at $37^{\circ} \mathrm{C}$. Sections were blocked for endogenous peroxidase activity by incubation with $0.5 \%$ hydrogen peroxide for 30 minutes at room temperature. Then, sections were washed in detergent containing washing buffer Tris buffered saline (TBS)-T (50 mm Tris- $\mathrm{HCl} ; 150 \mathrm{~mm} \mathrm{NaCl}, \mathrm{pH} 7.6$; $0.5 \%$ Triton $\mathrm{X}-100$ ) and exposed to primary antibodies overnight at $4^{\circ} \mathrm{C}$. All antibodies were diluted in TBS containing $0.25 \%$ bovine serum albumin. The $\mathrm{mAb}$ anti-uPA clone $\beta 10$ and mAb anti-TNP were used at $10 \mu \mathrm{g} / \mathrm{ml}$, whereas pAb1, pAb1 ${ }^{-}$, pAb2, and nonimmune rabbit lgG were used at $5 \mu \mathrm{g} / \mathrm{ml}$, except where otherwise stated. The mAb against CD31 was diluted 1:30. The site of antigen-antibody reaction was detected by biotinylated secondary antibodies followed by streptavidin complexed with biotinylated peroxidase using the $A B C$ kit as recommended by the manufacturer. Each antibody incubation was followed by a 15-minute wash in TBS-T. The presence of Triton $X-100$ in the washing buffer did not elute uPA antigen from the sections, because the specific uPA staining pattern was unaffected by its presence when tested on individual cryostat sections or individual paraffin sections from short-term formalin-fixed specimens. Sections were developed with $0.25 \mathrm{mg} / \mathrm{ml} 3$-amino-9ethylcarbazole (AEC) in $0.05 \mathrm{M}$ buffered acetic acid $(\mathrm{pH} \mathrm{5.0)}$ for 10 minutes. In addition, the following primary $\mathrm{mAb}$ were used in some of the experiments: anti-uPA clone $5(10-40 \mu \mathrm{g} / \mathrm{ml})$, clone $6(10-40$ $\mu \mathrm{g} / \mathrm{ml})$, \#394 $(10-40 \mu \mathrm{g} / \mathrm{ml})$ and \#377 $(40 \mu \mathrm{g} / \mathrm{ml})$, anti-hirudin $(10 \mu \mathrm{g} / \mathrm{ml})$, and anti-ovalbumin $(10 \mu \mathrm{g} / \mathrm{ml})$.

Cryostat sections. Cryostat sections $(8 \mu \mathrm{m})$ were air dried at room temperature and fixed in neutral buffered $4 \%$ formalin for 30 minutes at $4^{\circ} \mathrm{C}$. Sections 
were thoroughly washed in water and endogenous peroxidase blocked by $0.5 \% \mathrm{H}_{2} \mathrm{O}_{2}$ for 30 minutes. After a brief wash in TBS-T, sections were incubated with $10 \mu \mathrm{g} \mathrm{gG} / \mathrm{ml}$ of $\mathrm{pAb} 1, \mathrm{pAb} 1^{-}$, or clone $\beta 10$ overnight at $4^{\circ} \mathrm{C}$ and developed as described above.

\section{Comparison of uPA Immunohistochemistry and UPA mRNA In Situ Hybridization}

To compare the localization of UPA antigen and UPA mRNA, three adjacent $8-\mu \mathrm{m}$ cryostat sections from five invasive ductal carcinomas were prepared for immunohistochemistry or in situ hybridization as follows: (Section 1) immunohistochemical staining with polyclonal antibodies against uPA (pAb2, $10 \mu \mathrm{g} / \mathrm{ml}$ ) as specified above; (Section 2) in situ hybridization with antisense uPA probe; and (Section 3) in situ hybridization with sense UPA probe. The probes were transcribed from the plasmid phuPA10, and in situ hybridization was performed as described previously (Nielsen et al, 1996), with the following modification related to the use of cryostat sections: the cryostat sections were immediately heat-treated for 4 minutes at $60^{\circ} \mathrm{C}$ on a heating plate, then fixed overnight in $4 \%$ paraformaldehyde (PFA) at $4^{\circ} \mathrm{C}$, and, after a thorough wash in sterile water, heat-treated by boiling in citric acid buffer ( $\mathrm{pH} \mathrm{6.0)}$ in a microwave oven for 3 to 4 minutes. The sections were allowed to chill to room temperature and then dehydrated in alcohol solutions. The subsequent hybridization and washing steps were exactly as described (Nielsen et al, 1996). The hybridization pattern obtained with the antisense probe from phuPA10 was confirmed in a separate experiment, including the same breast tumor samples, by applying antisense and sense probes transcribed from the plasmid phuPA13, which contains a part of the UPA cDNA, but does not overlap that of the abovementioned plasmid phuPA10 (Pyke et al, 1991b).

\section{Double Immunofluorescence Microscopy}

Paraffin sections were prepared for double immunofluorescence microscopy by the standard procedure for uPA immunohistochemistry as described above, except that the blocking for endogenous peroxidase was omitted. After washing with TBS-T, the sections were incubated with 0.2 to $2 \mu \mathrm{g} / \mathrm{ml}$ of pAb1 anti-uPA $\operatorname{lgG}$ overnight at $4^{\circ} \mathrm{C}$. Detection was performed with biotinylated swine-anti-rabbit $(1: 100)$ followed by streptavidin conjugated alkaline phosphatase (1:200) and development with Fast Red for 15 minutes. After three washes in water, the sections were incubated overnight at $4^{\circ} \mathrm{C}$ with mouse $\mathrm{mAb}$ against either $\alpha$-sm-actin (1:50) or CD68 (1:50). Detection was subsequently done with FITC-conjugated goat-antimouse $(1: 200)$. Sections were mounted in $0.1 \%$ paraphenylenediamine in PBS-buffered $80 \%$ glycerol. FITC and Fast Red immunofluorescences were visualized in a conventional fluorescence microscope equipped with $470-490 / 520$ and $530-560 / 580 \mathrm{~nm}$ excitation/suppression filters, respectively. A Zeiss laser scan microscope (LSM 310, Carl Zeiss,
Oberkochen, Germany) equipped with an argon ion laser for $488 \mathrm{~nm}$ excitation and green and red channel detectors was used for definitive colocalization and photomicrographic reproduction. Scans were performed as overlays or consecutive green and red scans (Jensen et al, 1995).

\section{Scoring of Immunohistochemical Staining Intensities}

The intensity of UPA staining was scored by comparison with the strong and specific staining of paraffin sections obtained with $5 \mu \mathrm{g} / \mathrm{ml}$ of the polyclonal anti-uPA IgG preparation pAb2, using the standard fixation and staining procedure (Fig. 2A, Panel b). Staining intensities similar to the one obtained with 5 $\mu \mathrm{g} / \mathrm{ml}$ of pAb2 were scored $3+$. A score of $2+$ was given to staining intensities that were moderately weaker and in which fewer cells were stained. A weak staining intensity of even fewer cells was scored $1+$. No immunostaining or only occasional immunostaining of a few cells in the section was scored 0 . The staining intensities for the different UPA antibodies were evaluated on consecutive adjacent sections stained in parallel. For comparison of different fixation times and temperatures, the immunohistochemistry was performed in parallel on adjacent specimens obtained from the same tumors.

\section{Comparison of uPA Immunohistochemistry and UPA ELISA}

To determine whether the uPA staining intensity in the tissue sections was representative of the total UPA antigen level in the sample, six frozen samples of invasive ductal carcinoma were each divided into two halves. One half of each sample was processed for paraffin immunohistochemistry according to the standard procedure $(p A b 2,5 \mu \mathrm{g} / \mathrm{ml})$, and the other half was used for UPA ELISA measurements. The immunohistochemical staining intensities were scored as specified above (here giving the most strongly stained section the highest score: $3+$ ) independently by three observers (BSN, MS, and FR) unaware of the UPA ELISA results. All immunohistochemistry was performed on sections that were cut and stained in parallel on the same day with the same antibody dilution, chromogen development time, and incubation and washing times. Tissue extracts were obtained from the frozen samples after pulverization and extraction with Camiolo's extraction buffer $(3 \mu \mathrm{l} / \mathrm{mg})$ followed by centrifugation for 1 hour at $30,000 \mathrm{rpm}$ (Rosenquist et al, 1993). The supernatants were drawn off and measures of UPA antigen obtained by ELISA (type EUMIX-5; Monozyme, Copenhagen, Denmark). This ELISA is based on rabbit polyclonal antibodies as catching antibodies and three biotinylated monoclonal antibodies (clones 5, 6, and 16) as detecting antibodies (Pedersen et al, 1994b). Total protein in the extracts was measured with the bicinchoninic acid (BCA) protein assay kit (Pierce, Rockford, Illinois), and the ELISA values were normalized to the protein content. 


\section{Acknowledgements}

We thank Jan Grøndahl-Hansen and Marianne Nielsson for their generous gifts of the $\beta 10$ monoclonal antibody and affinity-purified polyclonal anti-uPA antibodies, respectively. We thank Dorte Holm, Lis Ströbech, Jill Poulsen, Eva Rahtkens Nielsen, and Pia Gottrup Knudsen for their excellent technical assistance. We thank lb J. Christensen for the statistical analysis.

\section{References}

Andreasen P, Kjøller L, Christensen L, and Duffy MJ (1997). The urokinase-type plasminogen activator system in cancer metastasis: A review. Int J Cancer 72:1-22.

Bianchi E, Cohen RL, Dai A, Thor AT, Shuman MA, and Smith HS (1995). Immunohistochemical localization of the plasminogen activator inhibitor- 1 in breast cancer. Int $\mathrm{J}$ Cancer 60:597-603.

Bianchi E, Cohen RL, Thor AT, Todd RF, Mizukami IF, Lawrence DA, Ljung BM, Shuman MA, and Smith HS (1994). The urokinase receptor is expressed in invasive breast cancer but not in normal breast tissue. Cancer Res 54:861-866.

Bloom HJG and Richardson WW (1957). Histological grading and prognosis in breast cancer. $\mathrm{Br} \mathrm{J}$ Cancer 11:359-377.

Brünner N, Stephens R, and Danø K (2000). Control of invasion and metastasis. In: Harris JR, editor. Diseases of the breast. Philadelphia: Lippincott Williams \& Wilkins, 367-375.

Bugge TH, Lund LR, Kombrinck KK, Nielsen BS, Holmbäck $\mathrm{K}$, Drew AF, Flick MJ, Witte DP, Danø K, and Degen JL (1998). Reduced metastasis of Polyoma virus middle $T$ antigen-induced mammary cancer in plasminogen-deficient mice. Oncogene 16:3097-3104.

Carriero MV, Franco P, Del Vecchio S, Massa O, Botti G, D'Aiuto G, Stoppelli MP, and Salvatore M (1994). Tissue distribution of soluble and receptor-bound urokinase in human breast cancer using a panel of monoclonal antibodies. Cancer Res 54:5445-5454.

Christensen L, Simonsen ACW, Heegaard CW, Moestrup SK, Andersen JA, and Andreasen PA (1996). Immunohistochemical localization of urokinase-type plasminogen activator, type-1 plasminogen-activator inhibitor, urokinase receptor and a2-macroglobulin receptor in human breast carcinomas. Int J Cancer 66:441-452.

Chung LW (1991). Fibroblasts are critical determinants in prostatic cancer growth and dissemination. Cancer Metastasis Rev 10:263-274.

Costantini V, Sidoni A, Deveglia R, Cazzato OA, Bellezza G, Ferri I, Bucciarelli E, and Nenci GG (1996). Combined overexpression of urokinase, urokinase receptor, and plasminogen activator inhibitor-1 is associated with breast cancer progression: An immunohistochemical comparison of normal, benign, and malignant breast tissues. Cancer 77:10791088.

Costantini V, Zacharski LR, Memoli VA, Kudryk BJ, Rousseau SM, and Stump DC (1991). Occurrence of components of fibrinolysis pathways in situ in neoplastic and nonneoplastic human breast tissue. Cancer Res 51:354-358.

Coussens LM, Tinkle CL, Hanahan D, and Werb Z (2000). MMP-9 supplied by bone marrow-derived cells contributes to skin carcinogenesis. Cell 103:481-490.
Damjanovich L, Turzó C, and Adány R (1994). Factors involved in the plasminogen activation system in human breast tumours. Thromb Haemost 71:684-691.

Danø K, Andreasen PA, Grøndahl-Hansen J, Kristensen P, Nielsen LS, and Skriver L (1985). Plasminogen activators, tissue degradation and cancer. Adv Cancer Res 44:139-266.

Danø K, Behrendt N, Brünner N, Ellis V, Ploug M, and Pyke C (1994). The urokinase receptor. Protein structure and role in plasminogen activation and cancer invasion. Fibrinolysis 8:189-203.

Danø K, Grøndahl-Hansen J, Eriksen J, Nielsen BS, Rømer J, and Pyke C (1993). The receptor for urokinase plasminogen activator. Stromal cell involvement in extracellular proteolysis during cancer invasion. In: Barret AJ and Bond J, editors. Proteolysis and protein turnover. London: Portland Press, 239-245.

Del Vecchio S, Stoppelli MP, Carriero MV, Fonti R, Massa O, Li PY, Botti G, Cerra M, D'Aiuto G, and Esposito G (1993). Human urokinase receptor concentration in malignant and benign breast tumors by in vitro quantitative autoradiography: Comparison with urokinase levels. Cancer Res 53:3198-3206.

Dublin E, Hanby A, Patel NK, Liebman R, and Barnes D (2000). Immunohistochemical expression of UPA, UPAR, and PAl-1 in breast carcinoma: Fibroblastic expression has strong associations with tumor pathology. Am J Pathol 157:1219-1227.

Duffy MJ, Reilly D, O'Sullivan C, O'Higgins N, Fennelly JJ, and Andreasen P (1990). Urokinase-plasminogen activator, a new and independent prognostic marker in breast cancer. Cancer Res 50:6827-6829.

Ellis V, Pyke C, Eriksen J, Solberg H, and Danø K (1992). The urokinase receptor: Involvement in cell surface proteolysis and cancer invasion. Ann NY Acad Sci 667:13-31.

Escot C, Zhao Y, Puech C, and Rochefort H (1996). Cellular localisation by in situ hybridisation of cathepsin D, stromely$\sin 3$, and urokinase plasminogen activator RNAs in breast cancer. Breast Cancer Res Treat 38:217-226.

Falini B, Flenghi L, Pileri S, Gambacorta M, Bigerna B, Durkop H, Eitelbach F, Thiele J, Pacini R, Cavaliere A, Martelli M, Cardarelli N, Sabattinin E, Poggi S, and Stein H (1993). PG-M1: A new monoclonal antibody directed against a fixative resistant epitope on the macrophage-restricted form of the CD68 molecule. Am J Pathol 142:1359-1372.

Grøndahl-Hansen J, Agerlin N, Munkholm-Larsen P, Bach F, Nielsen LS, Dombernowsky P, and Danø K (1988). Sensitive and specific enzyme-linked immunosorbent assay for urokinase-type plasminogen activator and its application to plasma from patients with breast cancer. J Lab Clin Med 111:42-51.

Grøndahl-Hansen J, Christensen IJ, Rosenquist C, Brünner N, Mouridsen HT, Danø K, and Blichert-Toft M (1993). High levels of urokinase-type plasminogen activator and its inhibitor PAl-1 in cytosolic extracts of breast carcinomas are associated with poor prognosis. Cancer Res 53:2513-2521.

Grøndahl-Hansen J, Peters HA, van Putten WLJ, Look MP, Pappot H, Rønne E, Danø K, Klijn JGM, Brünner N, and Foekens JA (1995). Prognostic significance of the receptor for urokinase plasminogen activator in breast cancer. Clin Cancer Res 1:1079-1087. 
Grøndahl-Hansen J, Ralfkiær E, Kirkeby LT, Kristensen P, Lund LR, and Danø K (1991). Localization of urokinase-type plasminogen activator in stromal cells in adenocarcinomas of the colon in humans. Am J Pathol 138:111-117.

Grøndahl-Hansen J, Ralfkiær E, Nielsen LS, Kristensen P, Frentz G, and Danø K (1987). Immunohistochemical localization of urokinase- and tissue-type plasminogen activators in psoriatic skin. J Invest Dermatol 88:28-32.

Hanahan D and Weinberg RA (2000). The hallmarks of cancer. Cell 100:57-70.

Hartmann G, Zide D, and Udenfriend S (1972). The use of dopamine-hydroxylase as a marker for the central noradrenergic nervous system in the rat brain. Proc Natl Acad Sci USA 69:2722-2726.

Heppner KJ, Matrisian LM, Jensen RA, and Rodgers WH (1996). Expression of most matrix metalloproteinase family members in breast cancer represents a tumor-induced host response. Am J Pathol 149:273-282.

Hewitt RE and Danø K (1996). Stromal cell expression of components of matrix degrading protease systems in human cancer. Enzyme Protein 49:163-173.

Jänicke F, Schmitt M, and Graeff H (1991). Clinical relevance of the urokinase-type and tissue-type plasminogen activators and of their type 1 inhibitor in breast cancer. Semin Thromb Hemost 17:303-312.

Jankun J, Merrick HW, and Goldblatt PJ (1993). Expression and localization of elements of the plasminogen activation system in benign breast disease and breast cancers. $\mathrm{J}$ Cell Biochem 53:135-144.

Jensen HL, Rygaard J, and Norrild B (1995). A time-related study of Brefeldin A effects in HSV-1 infected cultured human fibroblasts. APMIS 103:530-539.

Johnsen M, Lund LR, Rømer J, Almholt K, and Danø K (1998). Cancer invasion and tissue remodeling: Common themes in proteolytic matrix degradation. Curr Opin Cell Biol 10:667671.

Juhl BR, Nørgaard T, and Bjerrum OJ (1984). The effect of tween 20 on indirect immunoperoxidase staining of blood group antigen $\mathrm{A}$ in human urothelium. J Histochem Cytochem 32:935-941.

Kennedy S, Duffy MJ, Duggan C, Barnes C, Rafferty R, and Kramer MD (1998). Semi-quantitation of urokinase plasminogen activator and its receptor in breast carcinomas by immunocytochemistry. Br J Cancer 77:1638-1641.

Kerbel RS (1995). Significance of tumor-host interactions in cancer growth and metastases. Cancer Metastasis Rev 14: 259-262.

Kristensen P, Larsson L-I, Nielsen LS, Grøndahl-Hansen J, Andreasen PA, and Danø K (1984). Human endothelial cells contain one type of plasminogen activator. FEBS Lett 168: 33-37.

Kruithof EKO (1988). Plasminogen activator inhibitors: A review. Enzyme 40:113-121.

Larsson L-I (1981). Peptide immunocytochemistry. Prog Histochem Cytochem 13:1-85.

Larsson L-I, Skriver L, Nielsen LS, Grondahl Hansen J, Kristensen P, and Dano K (1984). Distribution of urokinasetype plasminogen activator immunoreactivity in the mouse. J Cell Biol 98:894-903.
Lund LR, Bjørn SF, Sternlicht MD, Nielsen BS, Solberg H, Usher PA, Østerby R, Christensen IJ, Stephens R, Bugge TH, Danø K, and Werb Z (2000). Lactational competence and involution of the mouse mammary gland require plasminogen. Development 127:4481-4492.

Lund LR, Rømer J, Bugge TH, Nielsen BS, Frandsen TL, Degen JL, Stephens R, and Danø K (1999). Functional overlap between two classes of matrix-degrading proteases in wound healing. EMBO J 18:4645-4656.

Lund LR, Rømer J, Thomasset N, Solberg H, Pyke C, Bissel M, Danø K, and Werb Z (1996). Two distinct phases of apoptosis in mammary gland involution: Proteinaseindependent and -dependent pathways. Development 122: 181-193.

Mignatti P and Rifkin DB (1993). Biology and biochemistry of proteinases in tumor invasion. Physiol Rev 73:161-195.

Nielsen BS, Sehested M, Kjeldsen L, Borregaard N, Rygaard $\mathrm{J}$, and Danø K (1997). Expression of matrix metalloprotease- 9 in vascular pericytes in human breast cancer. Lab Invest 77:345-355.

Nielsen BS, Sehested M, Timshel S, Pyke C, and Danø K (1996). Messenger RNA for urokinase plasminogen activator (UPA) is expressed in myofibroblasts adjacent to cancer cells in human breast cancer. Lab Invest 74:168-177.

Nielsen LS, Grøndahl-Hansen J, Andreasen PA, Skriver L, Zeuthen J, and Danø K (1986). Enzyme-linked immunosorbent assay for human urokinase-type plasminogen activator and its proenzyme using a combination of monoclonal and polyclonal antibodies. J Immunoassay 7:209-228.

Noel A, De Pauw-Gillet MC, Purnell G, Nusgens B, Lapiere CM, and Foidart JM (1993). Enhancement of tumorigenicity of human breast adenocarcinoma cells in nude mice by matrigel and fibroblasts. Br J Cancer 68:909-915.

Pappot H, Gaardsvoll H, Rømer J, Pedersen AN, GrøndahlHansen J, Pyke C, and Brünner N (1995). Plasminogen activator inhibitor type 1 in cancer: Therapeutic and prognostic implications. Biol Chem Hoppe Seyler 376:259-267.

Pedersen H, Brünner N, Francis D, Østerlind K, Rønne E, Hansen HH, Danø K, and Grøndahl-Hansen J (1994a). Prognostic impact of urokinase, urokinase receptor, and type 1 plasminogen activator inhibitor in squamous and large cell lung cancer tissue. Cancer Res 54:4671-4675.

Pedersen H, Grøndahl-Hansen J, Francis D, Østerlind K, Hansen HH, Danø K, and Brünner N (1994b). Urokinase and plasminogen activator inhibitor type 1 in pulmonary adenocarcinoma. Cancer Res 54:120-123.

Petersen LC, Lund LR, Nielsen LS, Danø K, and Skriver L (1988). One-chain urokinase-type plasminogen activator from human sarcoma cells is a proenzyme with little or no intrinsic activity. J Biol Chem 263:11189-11195.

Pyke C, Græm N, Ralfkiær E, Rønne E, Høyer-Hansen G, Brünner N, and Danø K (1993). Receptor for urokinase is present in tumor-associated macrophages in ductal breast carcinoma. Cancer Res 53:1911-1915.

Pyke C, Kristensen P, Ralfkiær E, Eriksen J, and Danø K (1991a). The plasminogen activation system in human colon cancer: Messenger RNA for the inhibitor PAl-1 is located in endothelial cells in the tumor stroma. Cancer Res 51:40674071.

Pyke C, Kristensen P, Ralfkiær E, Grøndahl-Hansen J, Eriksen J, Blasi F, and Danø K (1991b). Urokinase-type plasmin- 
ogen activator is expressed in stromal cells and its receptor in cancer cells at invasive foci in human colon adenocarcinomas. Am J Pathol 138:1059-1067.

Pyke C, Ralfkiær E, Rønne E, Høyer-Hansen G, Kirkeby L, and Danø K (1994). Immunohistochemical detection of the receptor for urokinase plasminogen activator in human colon cancer. Histopathol 24:131-138.

Roldan AL, Cubellis MV, Masucci M, Behrendt N, Lund LR, Danø K, Appella E, and Blasi F (1990). Cloning and expression of the receptor for human urokinase plasminogen activator, a central molecule in cell surface, plasmin dependent proeolysis. EMBO J 9:467-474.

Rømer J, Bugge TH, Pyke C, Lund LR, Flick MJ, Degen JL, and Danø K (1996). Impaired wound healing in mice with a disrupted plasminogen gene. Nat Med 2:287-292.

Rosenquist C, Thorpe SM, Danø K, and Grøndahl-Hansen J (1993). Enzyme-linked immunosorbent assay of urokinasetype plasminogen activator (UPA) in cytosolic extracts of human breast cancer tissue. Breast Cancer Res Treat 28: 223-229.

Sappino AP, Huarte J, Belin D, and Vassalli JD (1989). Plasminogen activators in tissue remodeling and invasion: mRNA localization in mouse ovaries and implanting embryos. J Cell Biol 109:2471-2479.

Sappino AP, Skalli O, Jackson B, Schürch W, and Gabbiani G (1988). Smooth-muscle differentiation in stromal cells of malignant and non-malignant breast tissues. Int $\mathrm{J}$ Cancer 41:707-712.

Seppa HE and Jarvinen M (1979). The main neutral protease of rat skin is a mast cell enzyme. Immunohistochemical localization of the enzyme in rat skin with the peroxidase-antiperoxidase (PAP) complex method. Acta Histochem 64:174-178.
Stephens RW, Nielsen HJ, Christensen IJ, ThorlaciusUssing O, Sorensen S, Dano K, and Brunner N (1999). Plasma urokinase receptor levels in patients with colorectal cancer: Relationship to prognosis. J Natl Cancer Inst 91:869-874

Sternberger LA (1979). Immunocytochemistry, New York: John Wiley \& Sons.

Sumiyoshi K, Baba S, Sakaguchi S, Urano T, Takada Y, and Takada A (1991). Increase in levels of plasminogen activator and type-1 plasminogen activator inhibitor in human breast cancer: Possible roles in tumor progression and metastasis. Thromb Res 63:59-71.

Tarin D (1992). Tumour metastasis. In: McGee JO, Isaacson PG, and Wright NA, editors. Oxford textbook of pathology. Oxford: Oxford University Press, 607-632.

Visscher DW, DeMattia F, Ottosen S, Sarkar FH, and Crissman JD (1995). Biologic and clinical significance of basic fibroblast growth factor immunostaining in breast carcinoma. Mod Pathol 8:665-670.

Visscher DW, Sarkar F, LoRusso P, Sakr W, Ottosen S, Wykes S, and Crissman JD (1993). Immunohistologic evaluation of invasion-associated proteases in breast carcinoma. Mod Pathol 6:302-306.

Werb Z (1997). ECM and cell surface proteolysis: Regulating cellular ecology. Cell 91:439-442.

Wolf C, Rouyer N, Lutz Y, Adida C, Loriot M, Bellocq JP, Chambon P, and Basset P (1993). Stromelysin 3 belongs to a subgroup of proteinases expressed in breast carcinoma fibroblastic cells and possibly implicated in tumor progression. Proc Natl Acad Sci USA 90:1843-1847. 